\title{
Reference Manual for Data Base on Nevada Well Logs
}

By Eva M. Bauer and Kenn D. Cartier

U.S. GEOLOGICAL SURVEY

Open-File Report 95-460

Prepared in cooperation with the

NEVADA DIVISION OF WATER RESOURCES

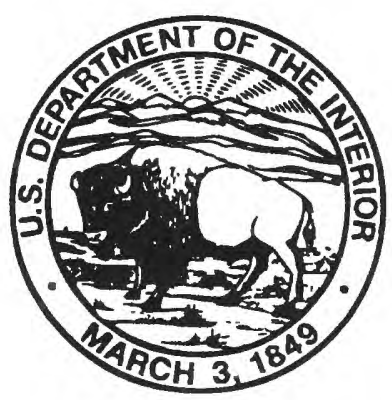

Carson City, Nevada 1995 


\title{
U.S. DEPARTMENT OF THE INTERIOR BRUCE BABBITT, Secretary
}

\author{
U.S. GEOLOGICAL SURVEY \\ GORDON P. EATON, Director
}

Any use of trade names in this publication is for descriptive purposes

only and does not constitute endorsement by the U.S. Government

For additional information

write to:

District Chief

U.S. Geological Survey 333 West Nye Lane, Room 203

Carson City, NV 89706-0866
Copies of this report can be purchased from:

U.S. Geological Survey Information Services Box 25286, MS 517 Denver Federal Center Denver, CO 80225-0046 


\section{CONTENTS}

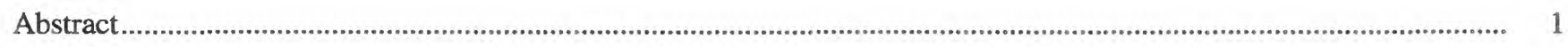

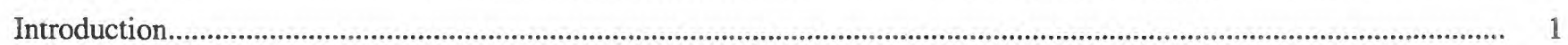

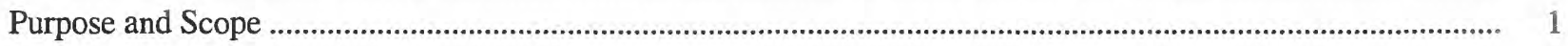

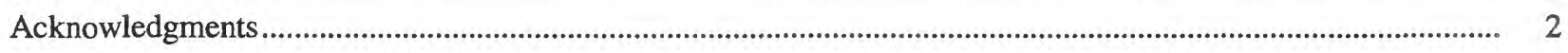

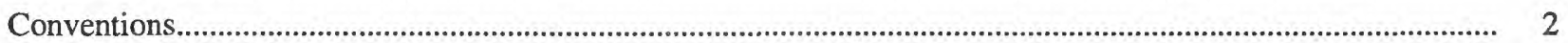

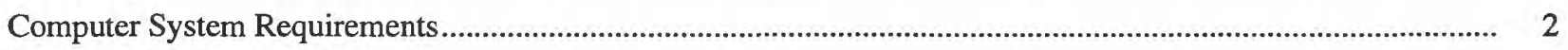

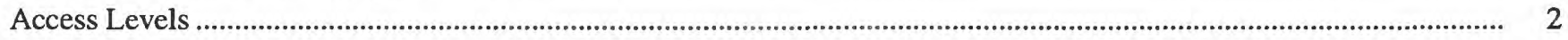

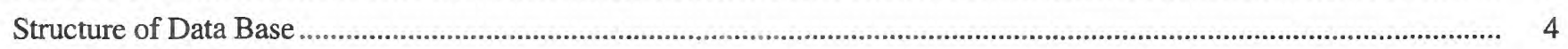

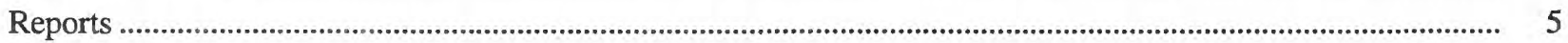

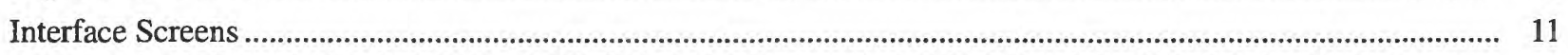

Data Append, Update, and Retrieve Menu Options ........................................................................ 11

Data Report Menu Options ............................................................................................................. 16

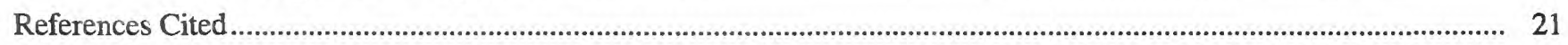

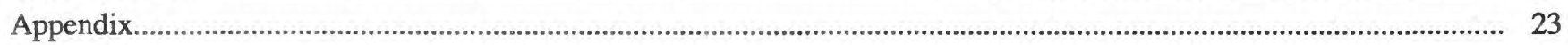

\section{FIGURES}

1-3. Screen images showing main menu for user access:

1. Level zero (data-base administrator) ...................................................................................................... 3

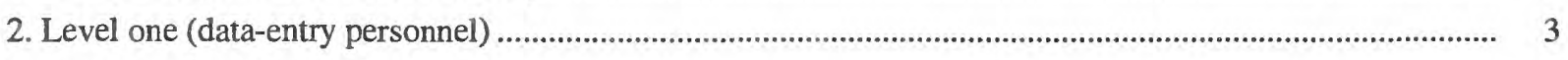

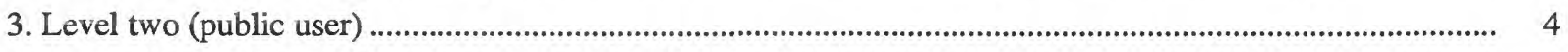

4. Diagram showing relations between tables of well-log data base ...................................................................

5-10. Screen images showing:

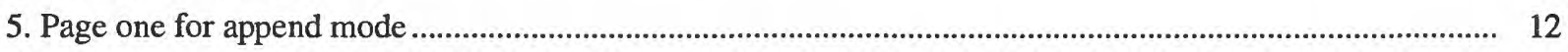

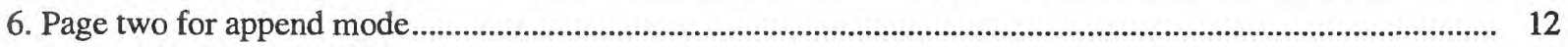

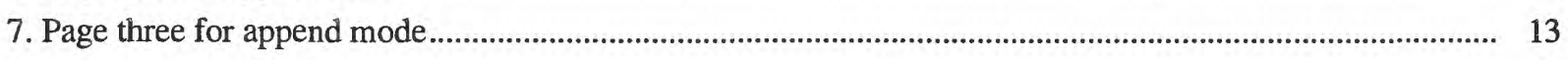

8. Page one for example query ........................................................................................................... 13

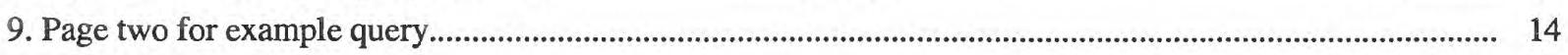

10. Page three for example query ...................................................................................................... 14

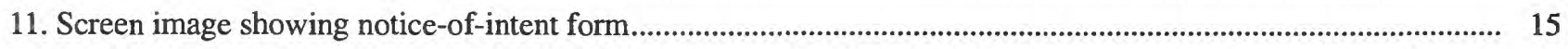

12-15. Screen images showing column headings for:

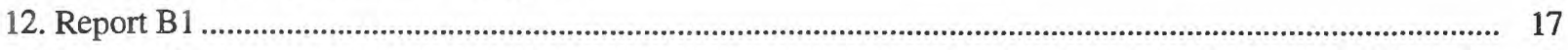

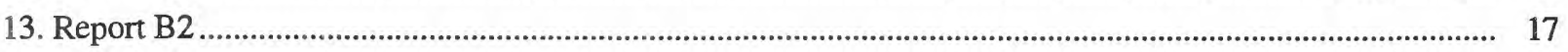

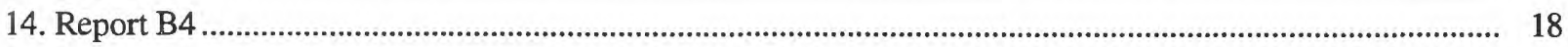

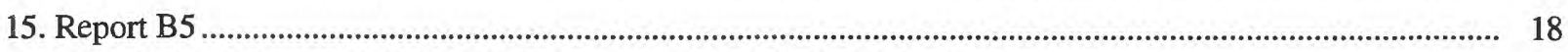

16-19. Screen images showing:

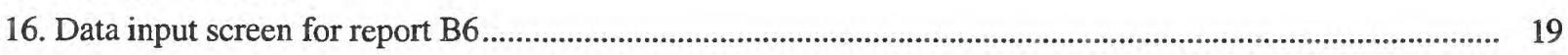

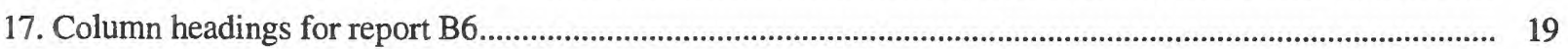

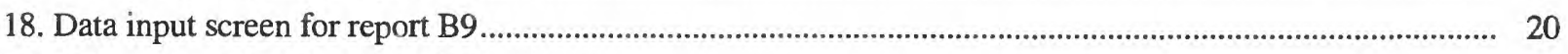

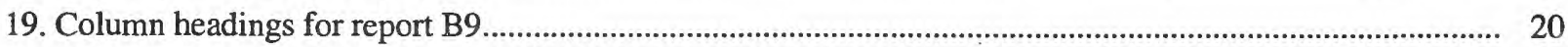




\section{TABLES}

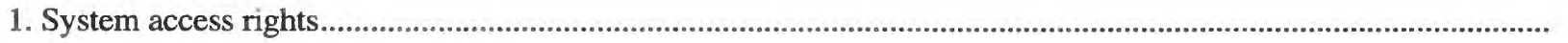

2-4. General description of data fields for:

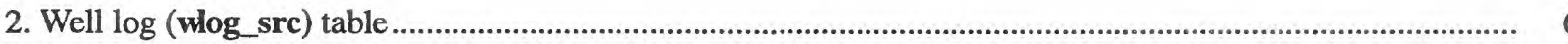

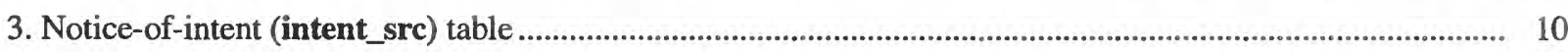

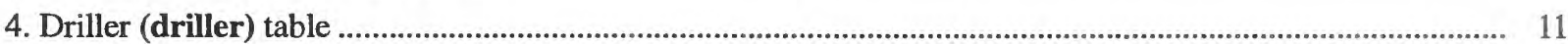

5-6. Field description for:

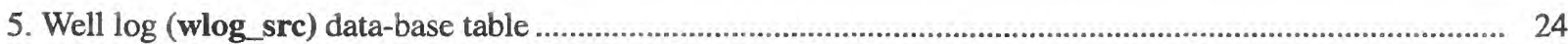

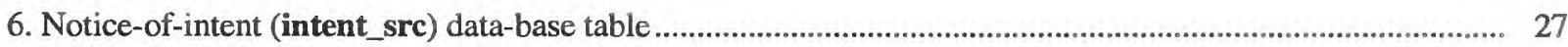

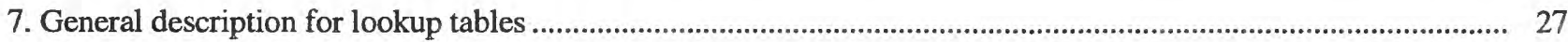

8-12. Codes used for:

8. Drilling methods in drilling_mthd_lut...................................................................................... 29

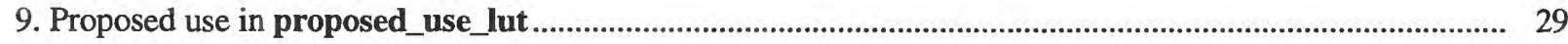

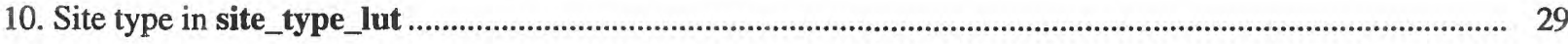

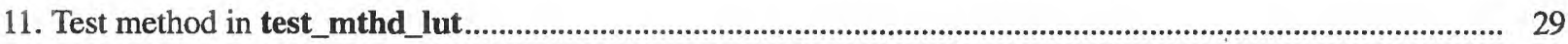

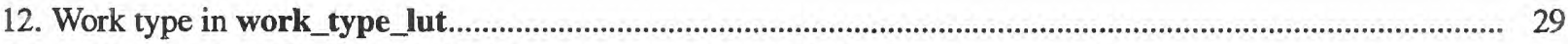




\title{
Reference Manual for Data Base on Nevada Well Logs
}

\author{
by Eva M. Bauer and Kenn D. Cartier
}

\section{ABSTRACT}

The U.S. Geological Survey and Nevada Division of Water Resources are cooperatively using a data base for managing well-log information for the State of Nevada. The Well-Log Data Base is part of an integrated system of computer data bases using the Ingres Relational Data-Base Management System, which allows efficient storage and access to water information from the State Engineer's office. The data base contains a main table, two ancillary tables, and nine lookup tables, as well as a menu-driven system for entering, updating, and reporting on the data. This reference guide outlines the general functions of the system and provides a brief description of data tables and data-entry screens.

\section{INTRODUCTION}

The U.S. Geological Survey (USGS) and Nevada Division of Water Resources (NDWR) have developed three integrated data bases for water-rights permit information, water-use information, and well-log data. This report documents one of the three data bases, the well-log data base.

The Well-Log Data-Base system (WLog) both stores and retrieves information required by the State of Nevada for new and existing wells. The data is indexed by a well-log number that can be referenced to the water-permit and water-use data bases. WLog is written in the Ingres Fourth Generation Language (4GL) with the forms-based user-interface program, Application By Forms $(\mathrm{ABF})$. The user interacts with the data base through screen menus consisting of four major components: routines for entering data and updating the data base, for making single-record queries, for compiling and producing reports, and utility routines for managing the data base. Data entry is validated using both forms-based and 4GL-based routines.

The current Ingres version of WLog was designed to replace a data base previously operated by the U.S. Geological Survey on a mainframe computer. The new data base allows the State to have greater control over data quality and data access. This gives USGS a data base that is more accessible for water-use investigations and for integration with the National Water Information System (NWIS) maintained by USGS.

The computer hardware used by the State consists of a network of non-graphics and graphics terminals connected to a UNIX-based file server. Because most users have access only to a textbased terminal, the application was developed using text-based 4GL. Coding was completed by USGS staff, working closely with NDWR staff to develop the specifications.

\section{Purpose and Scope}

This document serves as a reference guide to WLog developed for NDWR by USGS. This guide outlines the general functions of the system and provides a brief description of data tables and data-entry screens. This guide was written assuming that the user is familiar with NDWR's regulations for water-well drilling and with the contents of a well driller's report and has been instructed 
in how to enter and retrieve data. This guide is not intended for the novice user and does not provide detailed instructions for data input or retrieval. It is not a programming guide and does not describe the underlying code of the data base.

Many of the concepts and terms used in this report and the data-base application are described in reports by the Nevada Department of Conservation and Natural Resources. These include "Evolution of Nevada's Water Laws, as Related to the Development and Evaluation of the State's Water Resources, From 1866 to About 1960" (Shamberger, 1991) and "Regulations for Water Well and Related Drilling" (Nevada Division of Water Resources, 1990).

WLog has been used successfully for two years by NDWR and USGS for the management of well-log information. Although the software has been tested, the USGS and NDWR assume no responsibility for errors or omissions, or for damages resulting from the use of the system.

\section{Acknowledgments}

The authors acknowledge several individuals for their contribution to WLog. James L. Farnham, Tom Gallagher, and Kim Groenewold, of NDWR helped with the data specifications. James R. Swartwood and David B. Wood, of the USGS, are the original authors of the well-log data base written for the mainframe computer. John C. Watson, of the USGS, and Bernard L. Lap, formerly of the USGS, worked on the data-base tables.

\section{Conventions}

Bold lower case text, such as wlog_src, is used to identify data-base table names. Bold uppercase text, such as WELL_LOG, is used to identify data-field names in a table. Nonbold uppercase text in quotes, such as "NOI," is used to identify report names and column headings in reports.

\section{Computer System Requirements}

The WLog currently operates on a Data General AViiON 5200 file server running a UNIXbased operating system. Ingres Relational Data-Base Management System software is required. The user interface can be executed using either a non-graphics terminal or an X-based terminal. The data-base was written for storage and management of the State of Nevada's well-log data and all data ranges and specifications are in accordance with State of Nevada and USGS requirements.

\section{ACCESS LEVELS}

WLog runs at several access levels. These levels of permission control access to the data, application routines, screen displays, and reports. The system's access levels are summarized in table 1.

Table 1. System access rights

\begin{tabular}{|c|l|c|c|c|c|}
\hline $\begin{array}{c}\text { Access } \\
\text { level }\end{array}$ & \multicolumn{1}{|c|}{$\begin{array}{c}\text { User } \\
\text { description }\end{array}$} & $\begin{array}{c}\text { Data } \\
\text { retrieval }\end{array}$ & $\begin{array}{c}\text { Data } \\
\text { update }\end{array}$ & $\begin{array}{c}\text { Data } \\
\text { reports }\end{array}$ & $\begin{array}{c}\text { Data base } \\
\text { optimization }\end{array}$ \\
\hline \hline 0 & Data-base administrator & no & no & no & yes \\
\hline 1 & Data-entry personnel, full rights & yes & yes & yes & no \\
\hline 2 & Public user & yes & no & limited & no \\
\hline
\end{tabular}


Access level zero is for the data-base administrator. The administrator can establish or modify information such as user name, access level, and default printer. The data-base administrator also can optimize the data-base tables for maximum system performance using a suite of menu options. The main menu screen displayed for a user with access level zero is shown in figure 1.

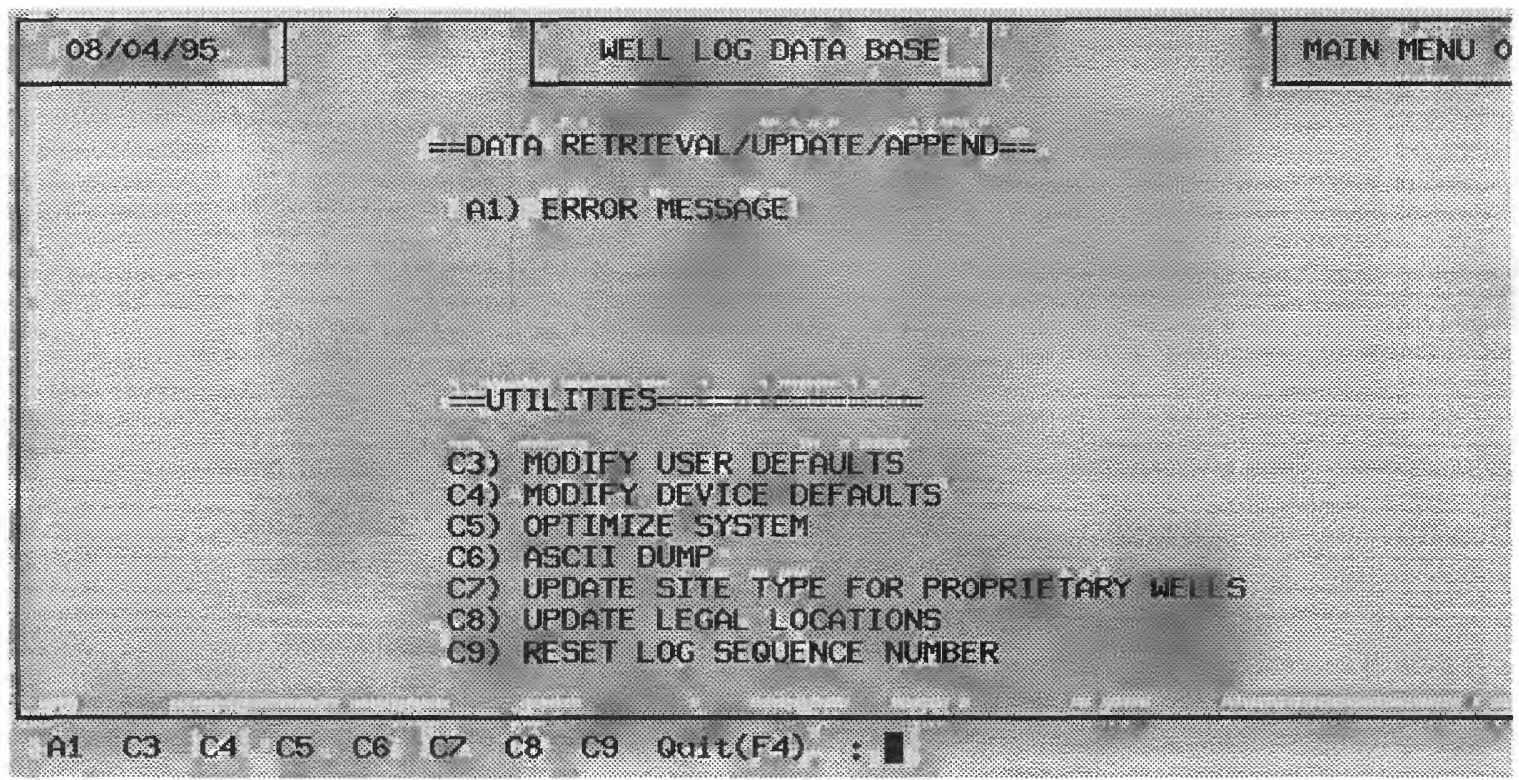

Figure 1. Main menu for user-access level zero (data-base administrator).

Access level one is for data-entry personnel who have full access. The user can perform data queries for specific records, append, and update data. Access level one also allows the user to access all available reports, including the restricted reports. The main menu screen displayed for a user with access level one is shown in figure 2.

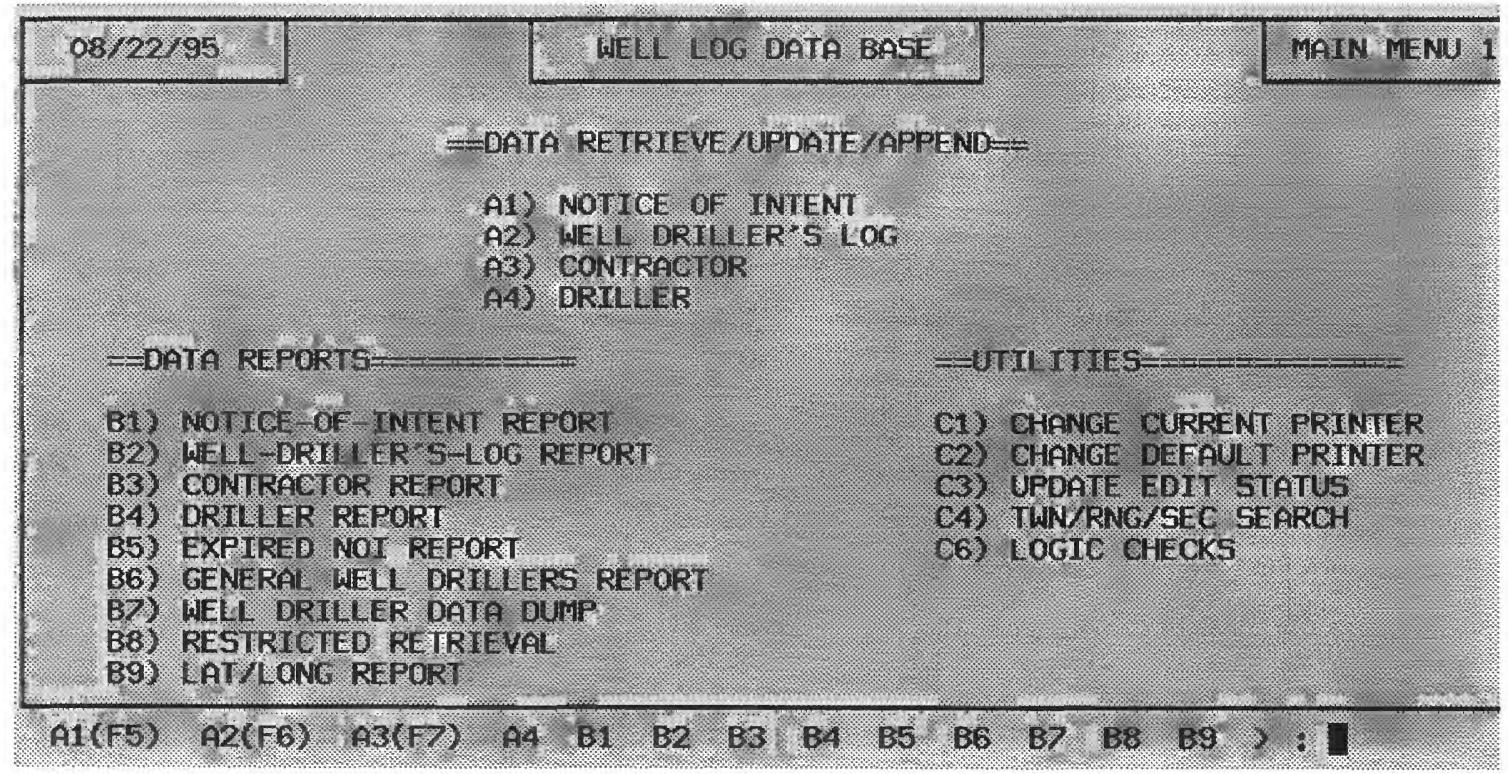

Figure 2. Main menu for user-access level one (data-entry personnel). 
Access level two is for public users and is the most restricted level. The user can make only limited data queries. At this level, public users can search for well-log information by several criteria, including well-log number, application number, location, and owner's name, but are not permitted to modify the data base or view confidential information. Access level two also allows access to seven of the nine reports. The main menu screen displayed for a user with access level two is shown in figure 3.

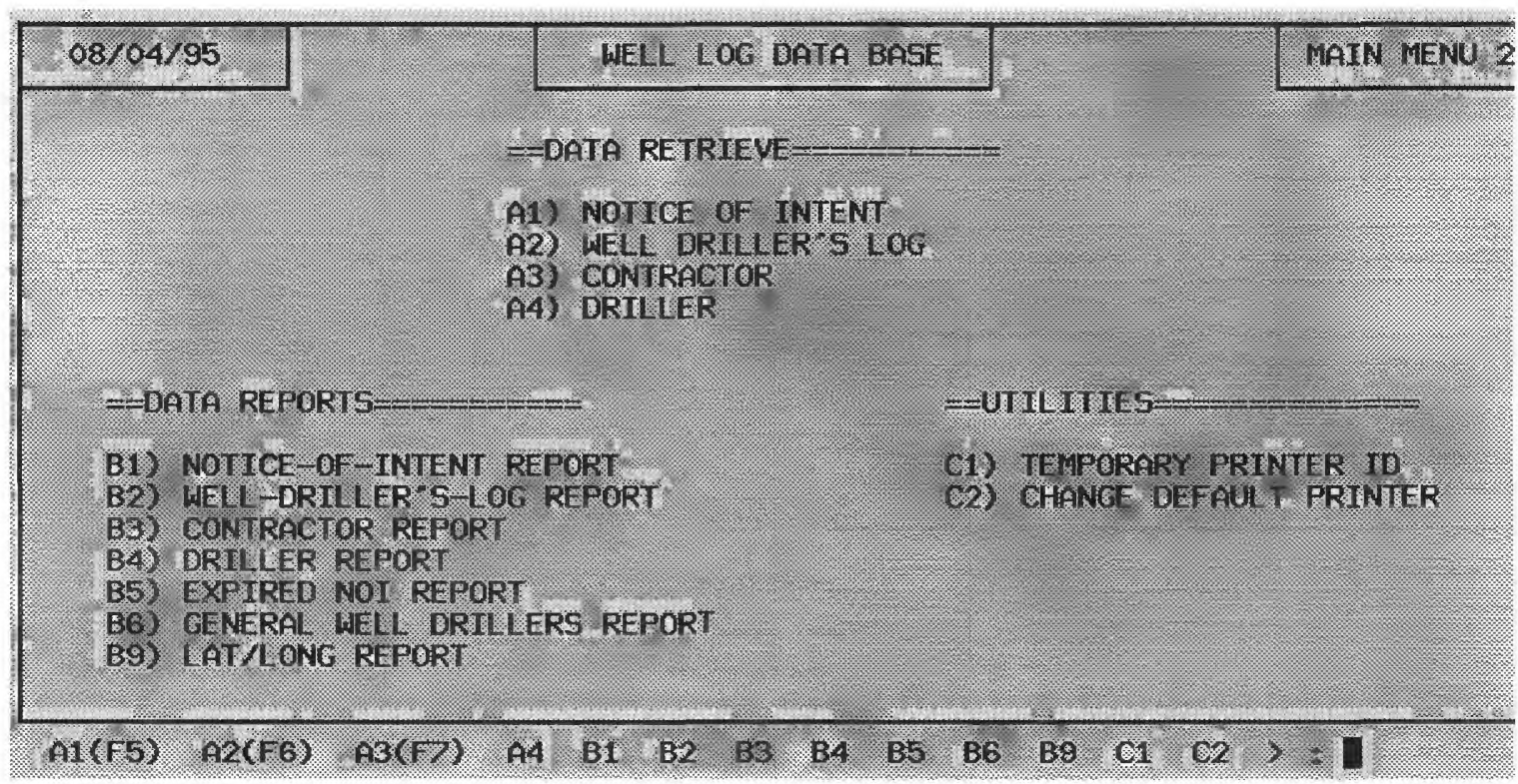

Figure 3. Main menu for user-access level two (public users).

\section{STRUCTURE OF DATA BASE}

The Ingres data base for WLog consists of a main table, two ancillary tables, nine lookup tables, and three system-maintenance tables. The main table (wlog_src) stores most of the well-log information. The ancillary tables (intent_src, and driller) contain information for the notice-ofintent forms and the driller at the well site. The ancillary tables are joined to the wlog_src table through one-to-many relations. The lookup tables (agency_lut, basin_lut, cont_lut, county_lut, drilling_mthd_lut, proposed_use_lut, site_type_lut, test_mthd_lut, and work_type_lut) give the user a list of valid codes for particular fields and provide the fully expanded name for abbreviations used in the main and ancillary tables. The system-maintenance tables (defaults_device, defaults_user, and error_messages) store user and printer information and system error messages. The relations between tables of the data base are shown in figure 4 .

The fields in the wlog_src table are listed and described in table 2. The fields in the intent_src and driller tables are listed and described in tables 3 and 4. A technical description of each field in wlog_src, including entry type, width, and template limits, is in table 5. A technical description of each field in the intent_src table, including entry type and width limits, is in table 6. No technical description of the driller table is given because driller information can only be retrieved, not appended or updated, through WLog. (The NDWR computer-system administrator is responsible for appending and updating the driller table.) A technical description of each field in the lookup tables, including entry type and width limits, is in table 7. Drilling-method codes and descriptions are in table 8. Proposed-use codes and descriptions are in table 9. Site-type codes and descriptions are in table 10. Test-method codes and descriptions are in table 11. Work-type codes and descriptions are in table 12. Tables 5-12 are in the appendix. 


\section{Nevada Well Log Data Base}

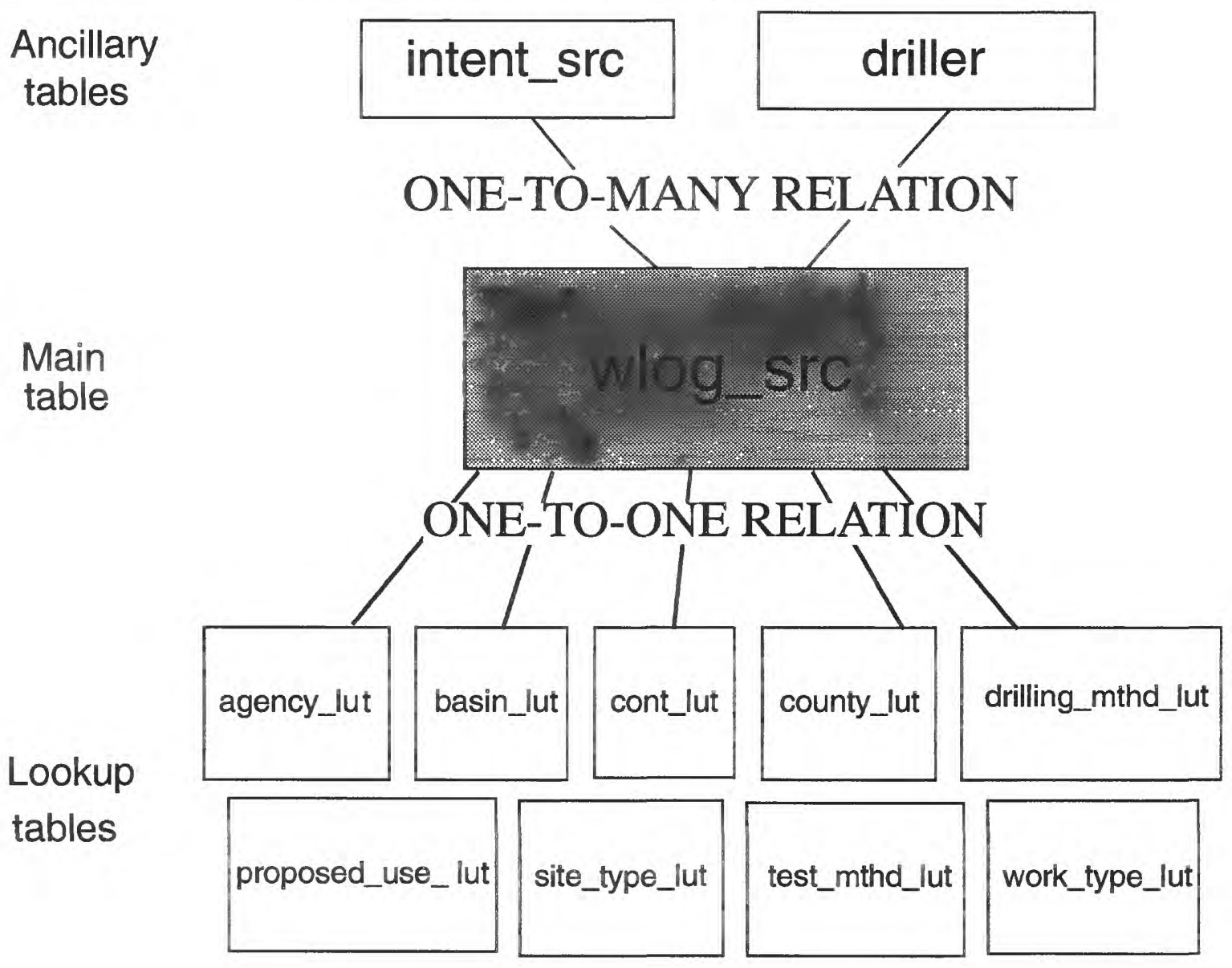

Figure 4. Relations between tables of the well-log data base.

\section{Reports}

Users with access levels one and two may invoke several reports for retrieving and organizing notice-of-intent, well-log, and drillers data. Seven reports are currently available for both access levels one and two: (1) "NOTICE-OF-INTENT REPORT" displays the information from the notice-of-intent-to-drill cards required by NDWR to be submitted before drilling; (2) "WELL_DRILLER'S LOG REPORT" displays a single well-log record, range of records, or prints the open records (records that have not been checked for entry error). Open records can only be retrieved by the user who entered the well-log record; (3) "CONTRACTOR REPORT" is currently not used; (4) "DRILLER REPORT" displays information on the drillers; (5) "EXPIRED NOI REPORT" displays the uncompleted notice-of-intent-to-drill cards older than 60 days from date drilled; (6) "GENERAL WELL DRILLERS REPORT" displays well-log information based on user selected criteria; and (7) "LAT/LONG REPORT" displays well-log information based on latitude and longitude location. Two additional restricted reports are available for users with access level one: (a) "WELL DRILLER DATA DUMP," which is similar to the "GENERAL WELL DRILLERS REPORT " but allows for display of all well-log records to date, excluding open and proprietary records, and is formatted to print on 11 inch by 14 inch paper; (b) "RESTRICTED RETRIEVAL" displays all well-log records to date, including open and proprietary records, based on user selected criteria. Reports can be viewed on the screen or sent to a printer. 
Table 2. General description of data fields for wlog_src table

[Abbreviations: NDWR, Nevada Division of Water Resources; PLSS, Public Land Survey System; USGS, U.S. Geological Survey]

\begin{tabular}{|c|c|c|}
\hline Field name & Description & Additional information \\
\hline SEQUENCE_NO & Sequence number & $\begin{array}{l}\text { Sequence number provides a unique field to link well-log data in } \\
\text { the separate tables. }\end{array}$ \\
\hline WELL_LOG & Log number & $\begin{array}{l}\text { Sequential number of particular Well Driller's Report. Value for } \\
\text { this field is assigned automatically for all new sites but can be } \\
\text { entered for historical sites. }\end{array}$ \\
\hline APP\# & Application number & $\begin{array}{l}\text { Request for water use (other than domestic or change of an } \\
\text { existing use); number is assigned by NDWR at time of filing. } \\
\text { After all legal requirements have been satisfied, application may } \\
\text { be permitted and subsequently certified. }\end{array}$ \\
\hline STATION_ID & Station identification & $\begin{array}{l}\text { Identification used by USGS' National Water Information System } \\
\text { database. }\end{array}$ \\
\hline NOTICE_OF_INTENT & Notice of intent & Number stamped on Notice-of-Intent-to-drill card. \\
\hline WAIVER_NO & Waiver number & $\begin{array}{l}\text { Waiver number assigned by NDWR to a well or wells for } \\
\text { exceptions to Nevada State well-drilling regulations. }\end{array}$ \\
\hline DATE_LOG_RCVD & Date received & $\begin{array}{l}\text { Date when Well Driller's Report was received by NDWR. Date is } \\
\text { stamped on front side of original well log. }\end{array}$ \\
\hline DATE_LOG_RCVD_ACC & Date received accuracy & $\begin{array}{l}\text { Valid codes are } \\
\mathrm{Y} \text { - date is missing month and day, only accurate to year } \\
\mathrm{M} \text { - date is missing day, only accurate to month } \\
\mathrm{D} \text { - date is accurate month, day and year }\end{array}$ \\
\hline SITE_TYPE & Site type & $\begin{array}{l}\text { Current status of well. } \\
\text { Valid codes are } \\
\mathrm{N} \text { - new } \\
\mathrm{E} \text { - existing } \\
\mathrm{P} \text { - proprietary, new (adhere to the following regulation) } \\
\text { Y - proprietary, existing (adhere to the following regulation) } \\
\text { Proprietary information on geothermal wells drilled within the past } \\
5 \text { years can not be accessed by the public. These wells are } \\
\text { determined by the water temperature on the well log (anything } \\
\text { above } 86 \text { degrees Fahrenheit). As required under Chapter } \\
534 \text { A.031 of the Nevada Revised Statutes, exploration and } \\
\text { subsurface information obtained as a result of a geothermal } \\
\text { project must be filed with the Department of Minerals within } 30 \\
\text { days after it is accumulated. The information is confidential for } \\
\text { a period of } 5 \text { years after the date of filing and may not be } \\
\text { disclosed during that time without the express written consent of } \\
\text { the operator of the project, except that it must be made available } \\
\text { by the Department to the State Engineer or any other agency of } \\
\text { the State upon request. The State Engineer or other agency shall } \\
\text { keep the information confidential for the required period. }\end{array}$ \\
\hline WORK_TYPE & Work type & $\begin{array}{l}\text { Type of work that was performed by the driller. } \\
\text { Valid codes are } \\
\text { D - deepen } \\
\text { G - geothermal } \\
\text { N - new (enter this value for new sites with one of the following } \\
\text { Proposed Uses) } \\
\text { O - other (explain in work type remarks) } \\
\text { P - plug } \\
\text { R - recondition }\end{array}$ \\
\hline WORK_TYPE_RMKS & Work type remarks & For work_type = "O", other; comments \\
\hline
\end{tabular}


Table 2. General description of data fields for wlog_src table --Continued

\begin{tabular}{|c|c|c|}
\hline Fleld name & Description & Additional Information \\
\hline PROPOSED_USE & Proposed use & $\begin{array}{l}\text { Indicates the principal use of the water at the site. } \\
\text { Valid codes are } \\
\text { A - air conditioning } \\
\text { B - bottling } \\
\text { C - commercial } \\
\text { D - dewater } \\
\text { E - power } \\
\text { F - fire } \\
\text { H - domestic } \\
\text { I - irrigation } \\
\text { J - industrial (cooling) } \\
\text { K - mining } \\
\text { M - medicinal } \\
\text { N - industrial } \\
\text { P - public supply (municipal) } \\
\text { Q - aquaculture } \\
\text { R - recreation } \\
\text { S - stock } \\
\text { T - institution } \\
\text { U - unused } \\
\text { Y - desalination } \\
\text { Z - other (explain in remarks) }\end{array}$ \\
\hline DRILLING_METHOD & Drilling method & $\begin{array}{l}\text { Method used to drill/construct the well. } \\
\text { Valid codes are } \\
\text { A - air-rotary } \\
\text { B - bored or augered } \\
\text { C - cable-tool } \\
\text { D - dug } \\
\text { H - hydraulic rotary (mud) } \\
\text { J - jetted } \\
\text { P - air percussion } \\
\text { R - reverse rotary } \\
\text { T - trenching } \\
\text { V - driven } \\
\text { W - drive and wash } \\
\text { Z - other (explain in remarks) }\end{array}$ \\
\hline $\mathrm{SC}$ & State county code & \begin{tabular}{|llll}
$\begin{array}{l}\text { County in which well is located. } \\
\text { County }\end{array}$ & Code & County & Code \\
Churchill & 32001 & Lincoln & 32017 \\
Clark & 32003 & Lyon & 32019 \\
Douglas & 32005 & Mineral & 32021 \\
Elko & 32007 & Nye & 32023 \\
Esmeralda & 32009 & Pershing & 32027 \\
Eureka & 32011 & Storey & 32029 \\
Humboldt & 32013 & Washoe & 32031 \\
Lander & 32015 & White Pine & 32033 \\
& & & \\
Independent City & Code & & \\
Carson City & 32510 &
\end{tabular} \\
\hline HA & Hydrographic area & Based on hydrographic numbering system. See Rush, 1968. \\
\hline TWN & Township & Location within PLSS township \\
\hline LEGAL_TWN & Township & $\begin{array}{l}\text { Legal format used by NDWR for township, i.e. } 16 \mathrm{~N} \text { for Township } \\
16 \text { North. }\end{array}$ \\
\hline RNG & Range & Location within PLSS range \\
\hline LEGAL_RNG & Range & $\begin{array}{l}\text { Legal format used by NDWR for range, i.e. } 20 \mathrm{E} \text { for Range } \\
20 \text { East. }\end{array}$ \\
\hline SEC & Section & Section number \\
\hline SEC_QUARTERS & Quarters & $\begin{array}{l}\text { Legal description of tract in which site is located recorded on } \\
\text { Driller's Log. Abbreviations NE, NW, SE, and SW (upper } \\
\text { cased) are used for the quarter (160 acres), quarter-quarter } \\
\text { ( } 40 \text { acres), or quarter-quarter-quarter (10 acres) designation. } \\
\text { Smallest subdivision is listed first. NE, northeast; NW, } \\
\text { northwest; SE, southeast; SW, southwest. }\end{array}$ \\
\hline
\end{tabular}


Table 2. General description of data fields for wlog_src table --Continued

\begin{tabular}{|c|c|c|}
\hline Field name & Description & Additional information \\
\hline LEGAL_QUARTERS & Quarters & Legal format used by NDWR for quarters. \\
\hline QUARTERS_SEQ & Quarter sequence & $\begin{array}{l}\text { Sites within smallest subdivision used are numbered sequentially } \\
\text { with one digit. }\end{array}$ \\
\hline REF & Reference & PLSS reference point \\
\hline ALTITUDE & Altitude & Average of surrounding ground surface elevation \\
\hline LATITUDE & Latitude & \\
\hline LONGITUDE & Longitude & \\
\hline LAT_LONG_ACC & $\begin{array}{l}\text { Latitude and longitude } \\
\text { accuracy }\end{array}$ & $\begin{array}{l}\text { Accuracy to which the site has been located denoted by a single } \\
\text { character field. Valid codes are } \\
\mathrm{F} \text { - measurement is accurate to } 5 \text { seconds, about } 505 \mathrm{feet} \\
\mathrm{T} \text { - measurement is accurate to } 10 \text { seconds, about } 1,010 \mathrm{feet} \\
\mathrm{M} \text { - the measurement is accurate to } 1 \text { minute, about } 6,060 \mathrm{feet}\end{array}$ \\
\hline OWNER_CURRENT & Current owner name & Owner name as shown on original well log. \\
\hline OWNER_ADDRESS & Owners address & Address of well site \\
\hline PARCEL_NO & Parcel number & Parcel number as shown on original well log. \\
\hline SUBDIVISION_NAME & Subdivision name & \\
\hline DATE_CMPLT & Date completed & Date drilling was completed. \\
\hline DATE_CMPLT_ACC & $\begin{array}{l}\text { Date completed } \\
\text { accuracy }\end{array}$ & $\begin{array}{l}\text { Valid codes are: } \\
\mathrm{Y} \text { - date is missing month and day, only accurate to the year } \\
\mathrm{M} \text { - date is missing day, only accurate to the month } \\
\mathrm{D} \text { - date is accurate month, day and year }\end{array}$ \\
\hline GRAVEL_PACKED & Gravel packed & $\begin{array}{l}\mathrm{Y}, \text { yes or } \mathrm{N}, \text { no. Indicates whether annulus (space between } \\
\text { borehole and well casing) surrounding perforated sections has } \\
\text { been gravel packed. }\end{array}$ \\
\hline DEPTH_SEAL & Depth of seal & $\begin{array}{l}\text { Depth to which annulus (space between borehole and well casing) } \\
\text { has been sealed. }\end{array}$ \\
\hline DEPTH_DRILLED & Depth drilled & Depth to bottom of borehole to the nearest foot \\
\hline DEPTH_BEDROCK & Depth to bedrock & Depth at which bedrock is encountered. \\
\hline AQUIFER_DESC & Aquifer type & \\
\hline DEPTH_CASED & Depth cased & $\begin{array}{l}\text { Maximum depth (bottom of last casing interval reported) to which } \\
\text { well was cased (completed) to the nearest } 1 \text { foot }\end{array}$ \\
\hline CSNG_DIAMETER & Casing diameter & Diameter of casing to nearest hundredth of an inch. \\
\hline CSNG_REDUCTIONS & Casing reductions & $\begin{array}{l}\text { Number of times diameter of casing is reduced with depth. Value } \\
\text { is zero if single casing diameter is used. }\end{array}$ \\
\hline TOP_PERF & Top perforation & Depth to top of first perforated interval, recorded to nearest foot. \\
\hline BOTTOM_PERF & Bottom perforation & $\begin{array}{l}\text { Depth to bottom of last perforated interval, recorded to nearest } \\
\text { foot. }\end{array}$ \\
\hline PERF_INTERVALS & Perforated intervals & Number of sections of perforated pipe or well screen. \\
\hline STATIC_WL & Static water level & $\begin{array}{l}\text { Depth-to-water measured on well-completion date, prior to } \\
\text { pumping the well and recorded to the nearest foot. }\end{array}$ \\
\hline TEMPERATURE & Temperature & Temperature of water \\
\hline YIELD & Yield & $\begin{array}{l}\text { Instantaneous rate at which well will produce water, in gallons per } \\
\text { minute (GPM). }\end{array}$ \\
\hline DRAWDOWN & Drawdown & Pumping water-level minus static water level. \\
\hline HOURS_PUMPED & Hours pumped & $\begin{array}{l}\text { Number of hours that water was continuously withdrawn from } \\
\text { well. }\end{array}$ \\
\hline
\end{tabular}


Table 2. General description of data fields for wlog_src table--Continued

\begin{tabular}{|c|c|c|}
\hline Fleld name & Description & Additional information \\
\hline TEST_METHOD & Test method & $\begin{array}{l}\text { Method of construction. Valid codes are } \\
\text { A - air lift } \\
\text { B - bucket } \\
\text { C - centrifugal pump } \\
\text { J - jet pump } \\
\text { P - piston pump } \\
\text { R - rotary } \\
\text { S - submergible pump } \\
\text { T - turbine } \\
\text { U - unknown } \\
\text { Z - other (explain in remarks) }\end{array}$ \\
\hline QUAL_CONST_DATA & $\begin{array}{l}\text { Quality of } \\
\text { construction data }\end{array}$ & $\begin{array}{l}\text { Indicates how thoroughly and legibly driller has reported required } \\
\text { information describing characteristics of well (excluding } \\
\text { lithology) on Well Driller's Report. Valid codes are } \\
\mathrm{E} \text { - excellent } \\
\mathrm{G} \text { - good } \\
\mathrm{F} \text { - fair } \\
\mathrm{P} \text { - poor } \\
\mathrm{N} \text { - not reported } \\
\mathrm{Z} \text { - other (explain in remarks) }\end{array}$ \\
\hline QUAL_LITH_DATA & $\begin{array}{l}\text { Quality of lithologic } \\
\text { data }\end{array}$ & $\begin{array}{l}\text { Indicates how thoroughly and legibly driller has described } \\
\text { lithology (types of material encountered) of borehole on Well } \\
\text { Driller's Report. Valid codes are } \\
\mathbb{E} \text { - excellent } \\
\text { G - good } \\
\text { F - fair } \\
\text { P - poor } \\
\text { N- not reported } \\
\text { Z - other (explain in remarks) }\end{array}$ \\
\hline REMARKS & Remarks & \\
\hline REMARKS_ADDITIONAL & Additional remarks & \\
\hline CONTRACTOR_LIC_NO & $\begin{array}{l}\text { Contractor's license } \\
\text { number }\end{array}$ & $\begin{array}{l}\text { Nevada contractor's license number issued by the State Board of } \\
\text { Contractors. }\end{array}$ \\
\hline CONTRACTOR_NAME & Contractor's name & Name of contractor drilling well \\
\hline CONTRACTOR_ADDRESS & Contractor's address & Address of contractor drilling well \\
\hline CONTRACTOR_DRLR_NO & $\begin{array}{l}\text { Contractor's driller } \\
\text { number }\end{array}$ & Driller number of contractor drilling well \\
\hline DRILLER_LIC_NO & $\begin{array}{l}\text { Driller's license } \\
\text { number }\end{array}$ & On-site driller's license number issued by NDWR. \\
\hline PROJECT_NO & Project number & \\
\hline DATE_FIELD_CHECK & Date field checked & Date on which site was inventoried (physically visited). \\
\hline SOURCE_AGENCY & Source agency code & $\begin{array}{l}\text { Agency or company where Driller's Log information originated. } \\
\text { Codes are found in source agency lookup table. }\end{array}$ \\
\hline USER_ID & User identification & User identification of individual who entered data. \\
\hline DATE_ENTRY & Date of entry & Date when record was entered. \\
\hline UPDATE_USER_ID & Update user id & Login identification of user who is updating record. \\
\hline DATE_UPDATE & Date of update & Date when record was updated. \\
\hline EDIT_STATUS & Edit Status & Valid codes are F, Final or $\mathrm{O}$, Open. \\
\hline WELL_START_DATE & Well start date & Date well drilling was started. \\
\hline PERF_LENGTH & Perforated Length & $\begin{array}{l}\text { Computed automatically by subtracting depth to top of first } \\
\text { perforated interval from depth to bottom to last perforated } \\
\text { interval. }\end{array}$ \\
\hline
\end{tabular}


Table 2. General description of data fields for wlog_src table --Continued

\begin{tabular}{|l|l|l|}
\hline \multicolumn{1}{|c|}{ Field name } & \multicolumn{1}{c|}{ Description } & \multicolumn{1}{c|}{ Additional information } \\
\hline \hline PUMPING_WL & Pumping water level & $\begin{array}{l}\text { Automatically computed drawdown plus static water level. } \\
\text { Maximum depth-to-water observed below land surface (depth at } \\
\text { which water-level stabilizes inside casing) while well is } \\
\text { pumping (producing water). }\end{array}$ \\
\hline SPECIF_CAPACITY & Specific capacity & Yield per unit of drawdown, automatically computed \\
\hline LOCAL_NO & Local number & $\begin{array}{l}\text { Combination of hydrographic area, township, range, section, } \\
\text { quarters, and quarter sequence }\end{array}$ \\
\hline OWNER_NAME_FWD & Owner name forward & $\begin{array}{l}\text { Owner's name will be displayed in view as first, middle initial, } \\
\text { last. }\end{array}$ \\
\hline GRAVEL_PACK_TOP & Gravel pack top & Top depth (feet) of gravel packed interval \\
\hline GRAVEL_PACK_BOT & Gravel pack bottom & Bottom depth (feet) of gravel packed interval \\
\hline
\end{tabular}

Table 3. General description of data fields for intent_src table

[Abbreviations: NDWR, Nevada Division of Water Resources; PLSS, Public land survey system; USGS, U.S. Geological Survey]

\begin{tabular}{|c|c|c|}
\hline Field name & Description & Additional information \\
\hline NOTICE_OF_INTENT & Notice of intent & Number stamped on Notice-of-Intent-to-drill card. \\
\hline APP\# & Application number & $\begin{array}{l}\text { Request for water use (other than domestic or change of an existing } \\
\text { use); number is assigned by NDWR at time of filing. After all legal } \\
\text { requirements have been satisfied, application may be permitted and } \\
\text { subsequently certified. }\end{array}$ \\
\hline DATE_SUB & Date submitted & Date notice-of-intent card was received by NDWR. \\
\hline DATE_DRL & Date drilled & Date that well is to be drilled as shown on notice-of-intent-to-drill card. \\
\hline HA & Hydrographic area & Based on hydrographic numbering system. See Rush, 1968. \\
\hline TWN & Township & Location within PLSS township \\
\hline RNG & Range & Location within PLSS range \\
\hline SEC & Section & Location within PLSS section \\
\hline SEC_QUARTERS & Quarters & $\begin{array}{l}\text { Legal description of the tract in which site is located recorded on } \\
\text { Driller's Log. Abbreviations NE, NW, SE, and SW (upper cased) are } \\
\text { used for quarter (160 acres), quarter-quarter ( } 40 \text { acres), or quarter- } \\
\text { quarter-quarter (10 acres) designation. Smallest subdivision is listed } \\
\text { first. NE, northeast; NW, northwest: SE, southeast: SW, southwest. }\end{array}$ \\
\hline QUARTERS_SEQ & Quarter sequence & $\begin{array}{l}\text { Sites within smallest subdivision used are numbered sequentially with } \\
\text { one digit. }\end{array}$ \\
\hline REF & Reference & PLSS reference point \\
\hline OWNER_ADDRESS & Owner's address & \\
\hline DRILLER_LIC_NO & Driller's license number & License number issued by NDWR. \\
\hline USER_ID & User identification & Login identification of individual who entered data. \\
\hline DATE_ENTRY & Date of entry & Date record was entered. \\
\hline SITE_ADDRESS & Site address & Address of drill site \\
\hline WAIVER_NO & Waiver number & $\begin{array}{l}\text { Waiver number assigned to a well or wells by NDWR for exceptions to } \\
\text { Nevada State well-drilling regulations. }\end{array}$ \\
\hline LOG_RCVD & Log received & Whether log was received or not. \\
\hline
\end{tabular}


Table 4. General description of data fields for driller table

\begin{tabular}{|c|c|c|}
\hline Field name & Description & Additional information \\
\hline LNAME & Last name & Last name of driller \\
\hline FNAME & First name & First name and middle initial of driller \\
\hline DRILL_NO & Driller number & Assigned by NDWR upon receiving a valid well driller's license \\
\hline TYPE & & $\begin{array}{l}\text { Type of well that driller is authorized to drill. Valid codes are } \\
\text { M - monitor } \\
\text { G - geothermal } \\
\text { FP - federal projects } \\
\text { P - plugging } \\
\text { If blank, type is assumed to be water. }\end{array}$ \\
\hline COMPANY & & Company driller works for, if applicable \\
\hline ADDRESS & $\begin{array}{l}\text { Business street address } \\
\text { of driller }\end{array}$ & $\begin{array}{l}\text { Street address or P. O. Box of driller or company driller works for (if requested } \\
\text { instead by driller) }\end{array}$ \\
\hline CITY & & City of address specified by driller \\
\hline ST & State & State of address specified by driller \\
\hline ZIP & Zip code & Zip code of address specified by driller \\
\hline PHONE & Phone number & $\begin{array}{l}\text { Phone number of driller or company driller works for (if requested instead by } \\
\text { driller) }\end{array}$ \\
\hline CONTRLIC & Contractor's license & $\begin{array}{l}\text { Assigned by the State Board of Contractors if driller owns his own drilling } \\
\text { equipment }\end{array}$ \\
\hline CLASS & & Assigned by the State Contractor's Board, usually equal to $\mathrm{C} 23$ \\
\hline STATUS & Status of driller license & Active or expired \\
\hline
\end{tabular}

\section{Interface Screens}

The user, depending upon access level, performs data appends, updates, and retrievals or produces reports through a series of interface screens. The main menu for each access level displays the set of menu options available to the user (see figs. 1-3).

\section{Data Append, Update, and Retrieve Menu Options}

Data append is used to add a new record; data update is used to change an existing record. Only users with access level one can append or update data. Data retrieve is used to display data without the ability to update the data. Users with access level one or two can retrieve data. Data in the WLog is appended, updated, and retrieved through the following main menu options:

Option A1 - NOTICE OF INTENT. The user can append, update, or retrieve notice-of-intent information.

Option A2 - WELL DRILLER'S LOG. The user can append, update, or retrieve well-log information.

Option A3 - CONTRACTOR. This option currently is not used for accessing contractor information; it could be used in future versions of the system.

Option A4 - DRILLER. The user can retrieve driller information.

The data for appending or updating are displayed on a series of three screen pages. These screens are shown in figures 5-7. The interface screens guide the user through the data available for a specific well-log record. Retrieved data is also displayed in a series of three screen pages. These screens are shown in figures 8-10. The notice-of-intent form is shown in figure 11 . 


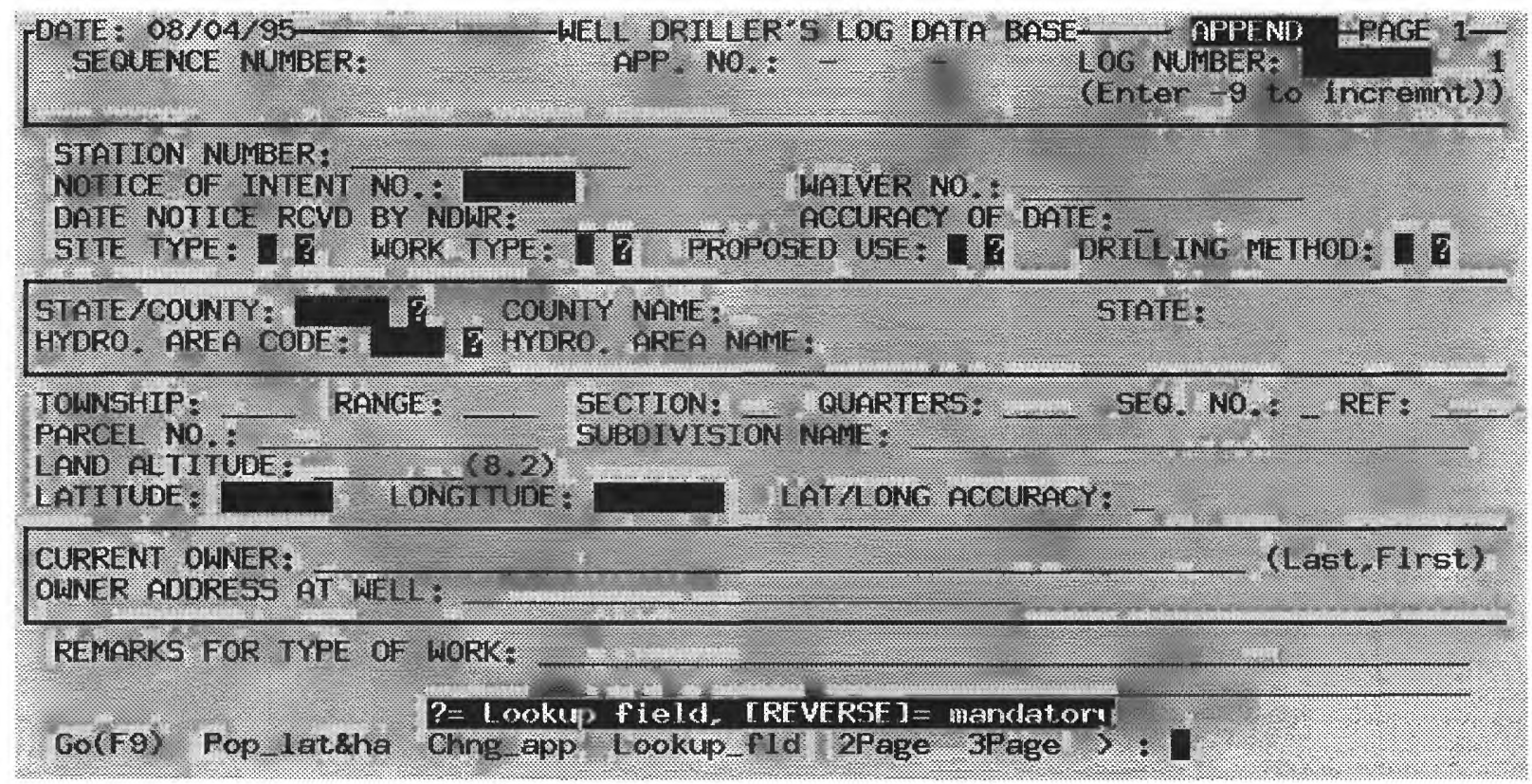

Figure 5. Page one for append/update. Screen is similar when in update mode.

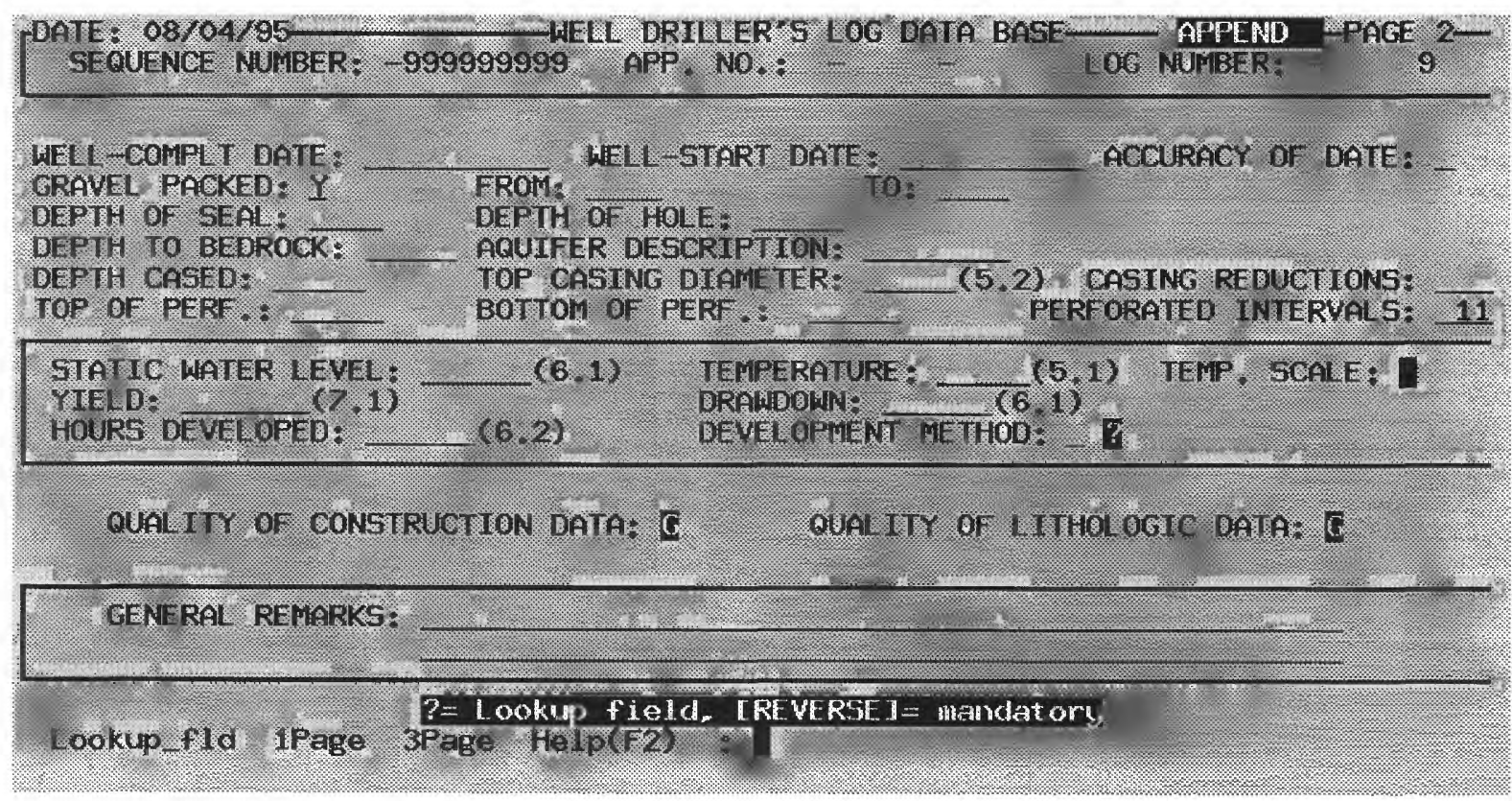

Figure 6. Page two for append/update. Screen is similar when in update mode. 


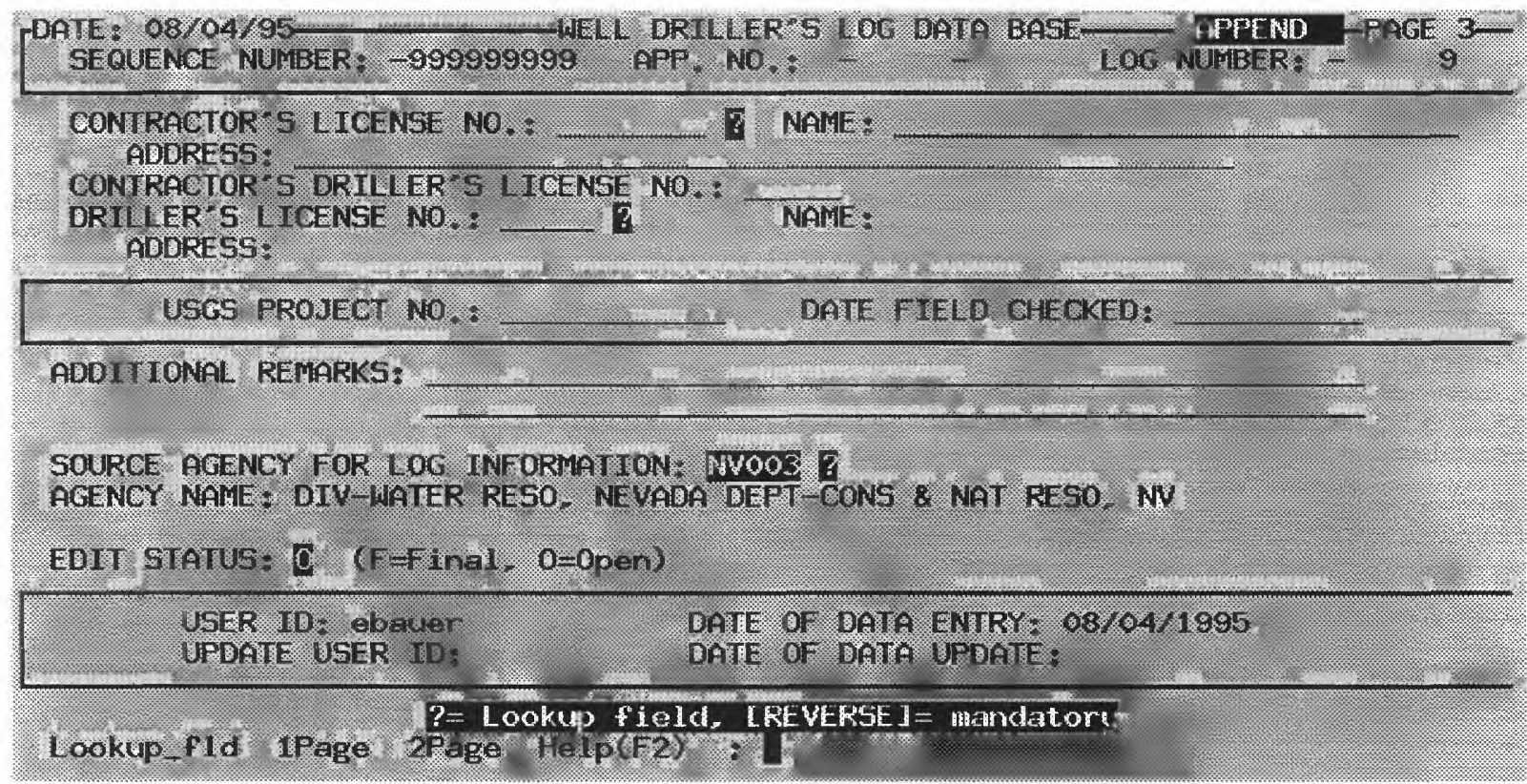

Figure 7. Page three for append/update. Screen is similar when in update mode.

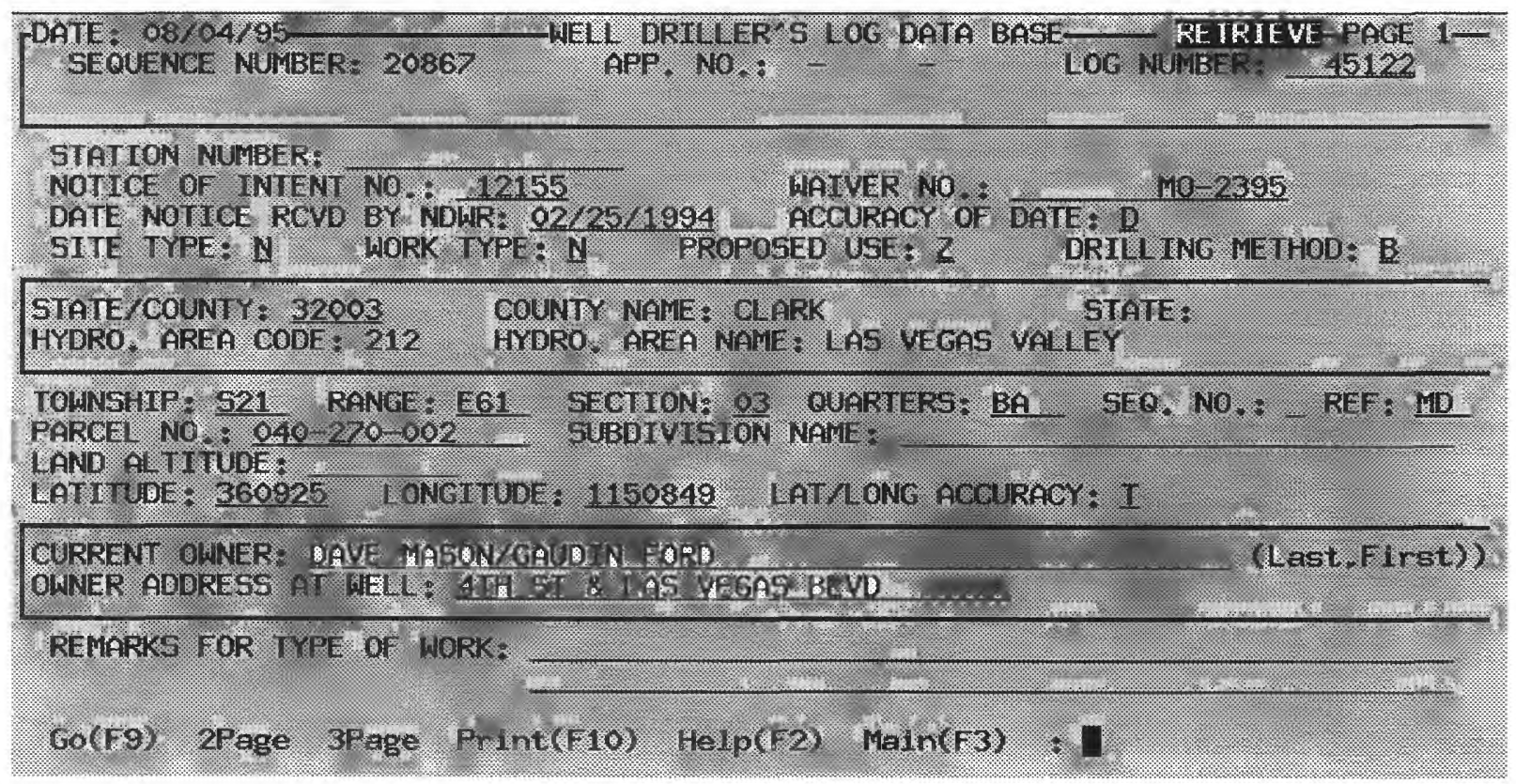

Figure 8. Page one for example query. 


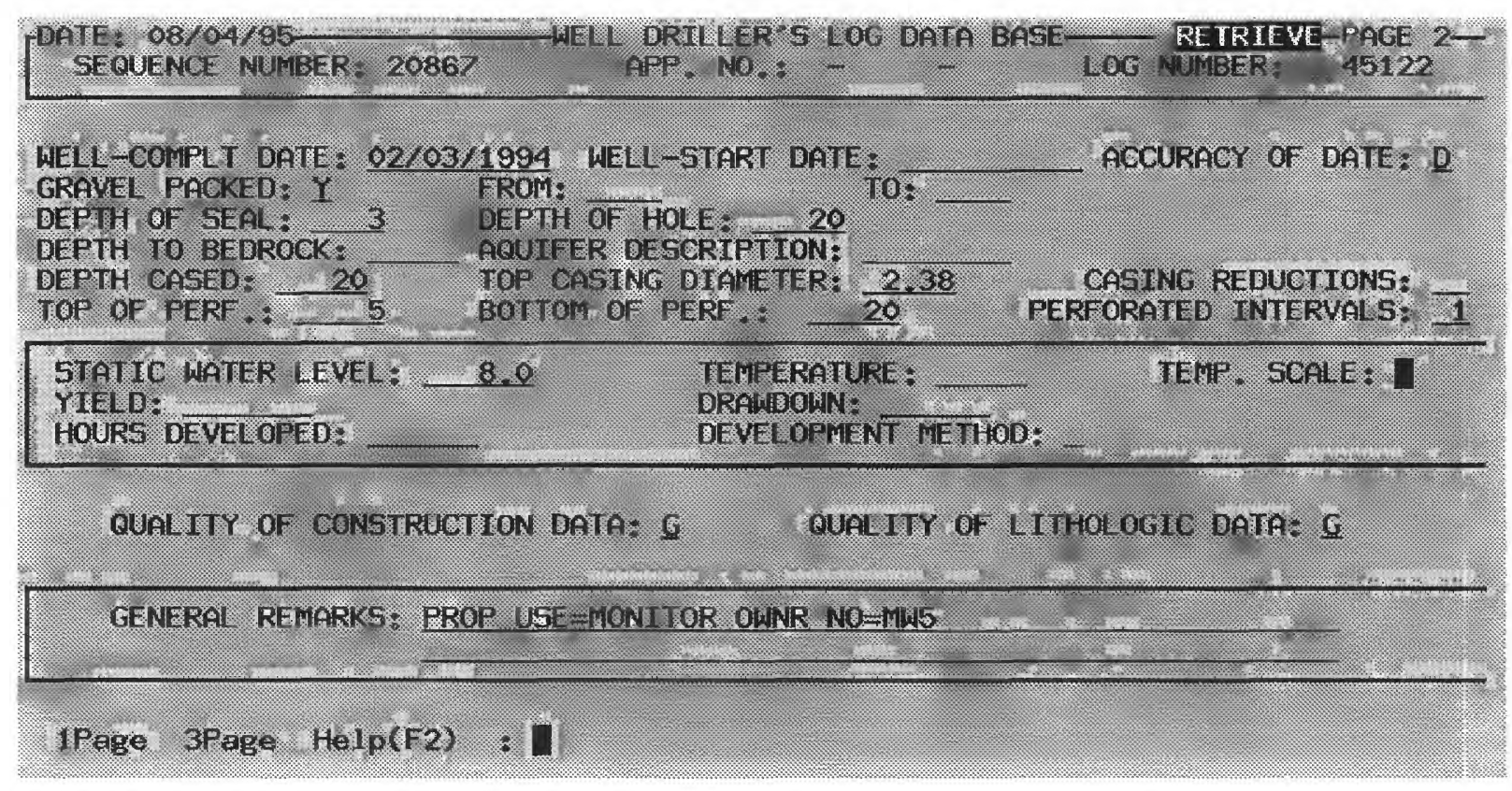

Figure 9. Page two for example query.

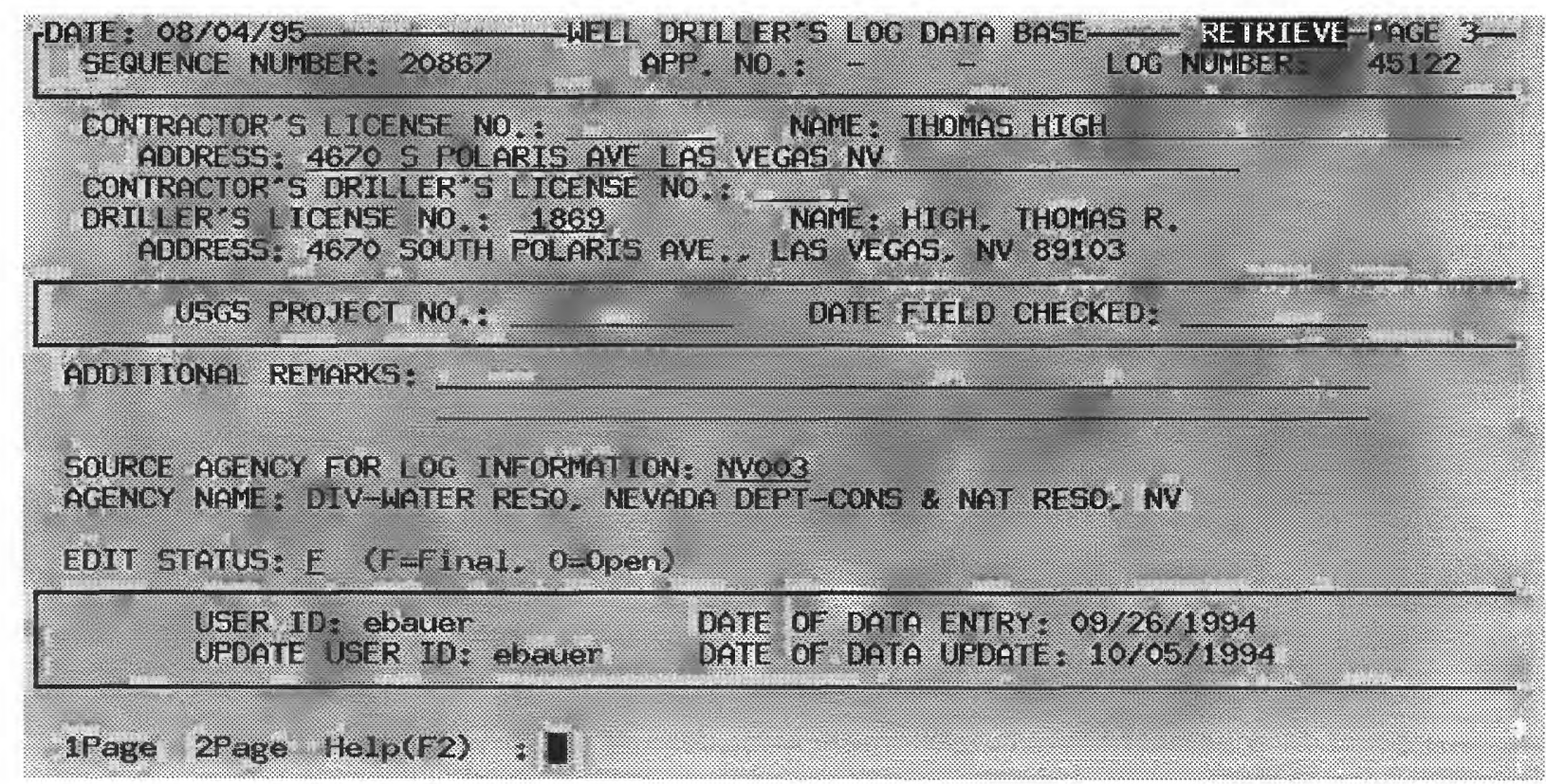

Figure 10. Page three for example query. 


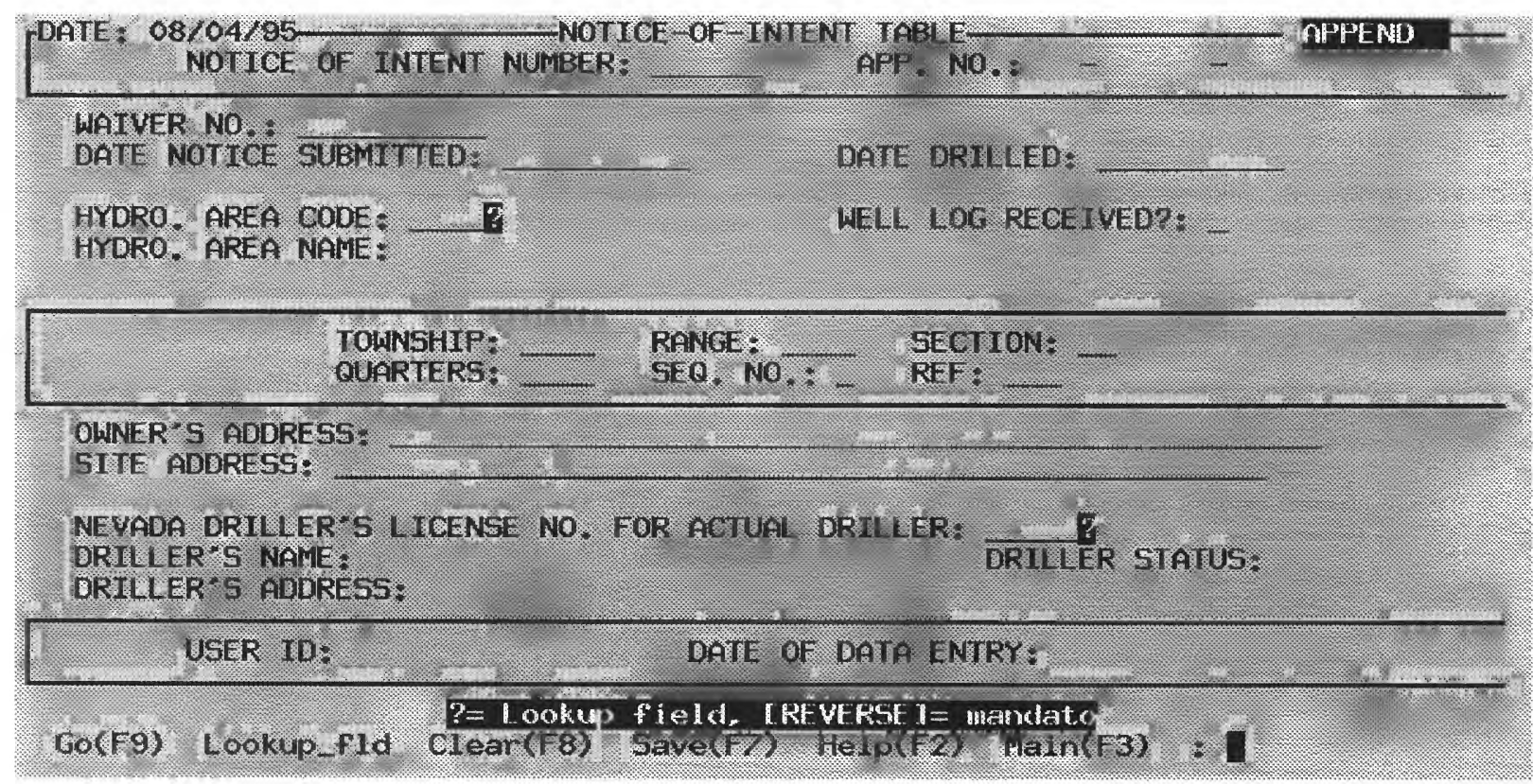

Figure 11. Notice-of-intent form. 


\section{Data Report Menu Options}

Reports are accessed by the following menu options:

Option B1 - "NOTICE-OF-INTENT REPORT." The "NOTICE-OF-INTENT REPORT" column headings are shown in figure 12 . The user can retrieve notice-of-intent records from a specific township and range, or can retrieve all notice-of-intent records.

Option B2 - "WELL-DRILLER'S LOG REPORT." The "WELL-DRILLER'S LOG REPORT" column headings are shown in figure 13 . The user can retrieve a single record, a single open record, or a series of open records. Open records are records for which data for a particular well log has been entered, but not yet checked for data-entry errors. Open records can only be retrieved by the user who entered the well-log record.

Option B3 - "CONTRACTOR REPORT." The "CONTRACTOR REPORT" is not implemented at this time. It could be used in future versions of the system.

Option B4 - "DRILLER REPORT." The "DRILLER REPORT" column headings are shown in figure 14. In addition, the driller's address and phone number, if given, are printed on the following line. The user can retrieve data on the basis of the driller status or can retrieve data on all the drillers. The report is sorted by driller's name.

Option B5 - "EXPIRED NOI REPORT." The "EXPIRED NOI REPORT" column headings are shown in figure 15 . The report lists all uncompleted notices older than 60 days from the date drilled. The report is sorted by notice-of-intent number.

Option B6 - "GENERAL WELL DRILLERS REPORT." The "GENERAL WELL DRILLERS REPORT" input screen is shown in figure 16 . The user must specify at least one selection criterion for data retrieval, such as location, owner, start and end date, proposed use, etc. The data base will retrieve all non-proprietary final records that match all criteria the user selected. Output headings for the resulting report are shown in figure 17.

Option B7 - "WELL DRILLER DATA DUMP." The input screen and report output headings for the "WELL DRILLER DATA DUMP" are identical to those for Option B6, the “GENERAL WELL DRILLERS REPORT." In option B6, a user must specify at least one search criterion. If no search criteria are specified in option B7, all well-log records to date, except proprietary and open records, will be retrieved and the report will be formatted for 11 inch by 14 inch paper.

Option B8 - "RESTRICTED RETRIEVAL." The input screen and report-output headings for the "RESTRICTED RETRIEVAL" are identical to those for Option B6, the "GENERAL WELL DRILLERS REPORT." In Option B8, a user must have an access level of one to retrieve proprietary and open records. The user has the option of specifying selection criteria or leaving the input screen blank and retrieving all records to date.

Option B9 - "LAT/LONG REPORT." The "LAT/LONG REPORT" input screen is shown in figure 18. It is similar to Option B6 "GENERAL WELL DRILLERS REPORT" in that the user must specify at least one selection criterion for data retrieval, but, the user can also specify a minimum and maximum latitude and longitude. This allows for well$\log$ data retrieval for a four-sided area. Output headings for the resulting report are shown in figure 19. 


\begin{tabular}{|c|c|c|c|c|c|c|c|c|c|c|c|c|c|}
\hline & & & & Notic & as of & Inte & & & & & & & \\
\hline $\begin{array}{l}\text { Not } 1 \text { ce } \\
\text { of } \\
\text { Intent }\end{array}$ & $\begin{array}{l}\text { Applinicath } \\
\text { Number }\end{array}$ & $\begin{array}{l}\text { Gate } \\
\text { Notice } \\
\text { Submiltited }\end{array}$ & $\begin{array}{l}\text { Dater } \\
\text { Orililed }\end{array}$ & $\begin{array}{l}\text { Hydro } \\
\text { Basin }\end{array}$ & two & Rng & See & aren & Seq & Re? & milir & $\begin{array}{l}\text { User } \\
\text { Io }\end{array}$ & $\begin{array}{l}\text { Entry } \\
\text { Bate }\end{array}$ \\
\hline 2771 & & $03 / 16,95$ & $03 / 17 / 95$ & 61 & N36. & 550 & 30 & 89 & & mo & 1410 & mdill lon & $03 / 16 / 05$ \\
\hline 22949 & 58355 & $04 / 200 / 95$ & $04 / 119 / 95$ & 61 & 1936 & 1550 & 19 & Dr & & MD & 1618 & mol ty lon & $041,21,95$ \\
\hline 22951 & 55141 & $04 / 20 / 95$ & $04 / 19 / 95$ & 61 & N36. & E50 & 19 & AC & & $\mathrm{MD}$ & 16116 & indt Whan & $04 / 21 / 95$ \\
\hline 27956 & 58355 & $0.4,20 \% 95$ & $04 / 19 / 95$ & 81 & 1336 & 155 & 20 & CB & & 10 & 1646 & mall I I Ion & $04 / 21 / 95$ \\
\hline 2775 & 56140 & $02 / 14 / 95$ & $02 / 15 / 95$ & 61 & 136 & E50 & 18 & $\mathrm{DB}$ & & Mo & 1410 & mdi I lion & $022116 / 95$ \\
\hline
\end{tabular}

Figure 12. Column headings for report B1, Notice-of-Intent Report.

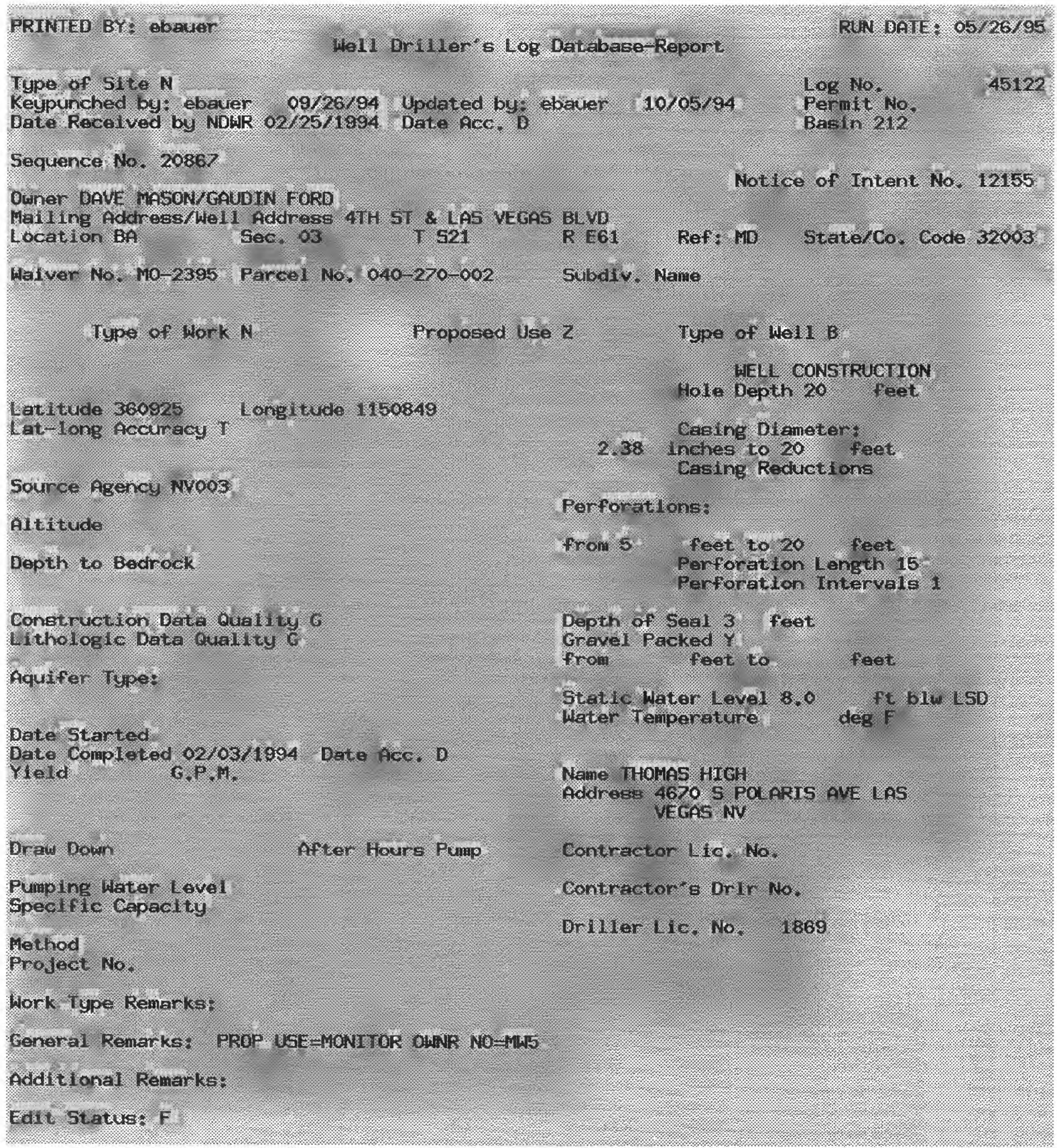

Figure 13. Column headings for report B2, Well-Driller's Log Report. 

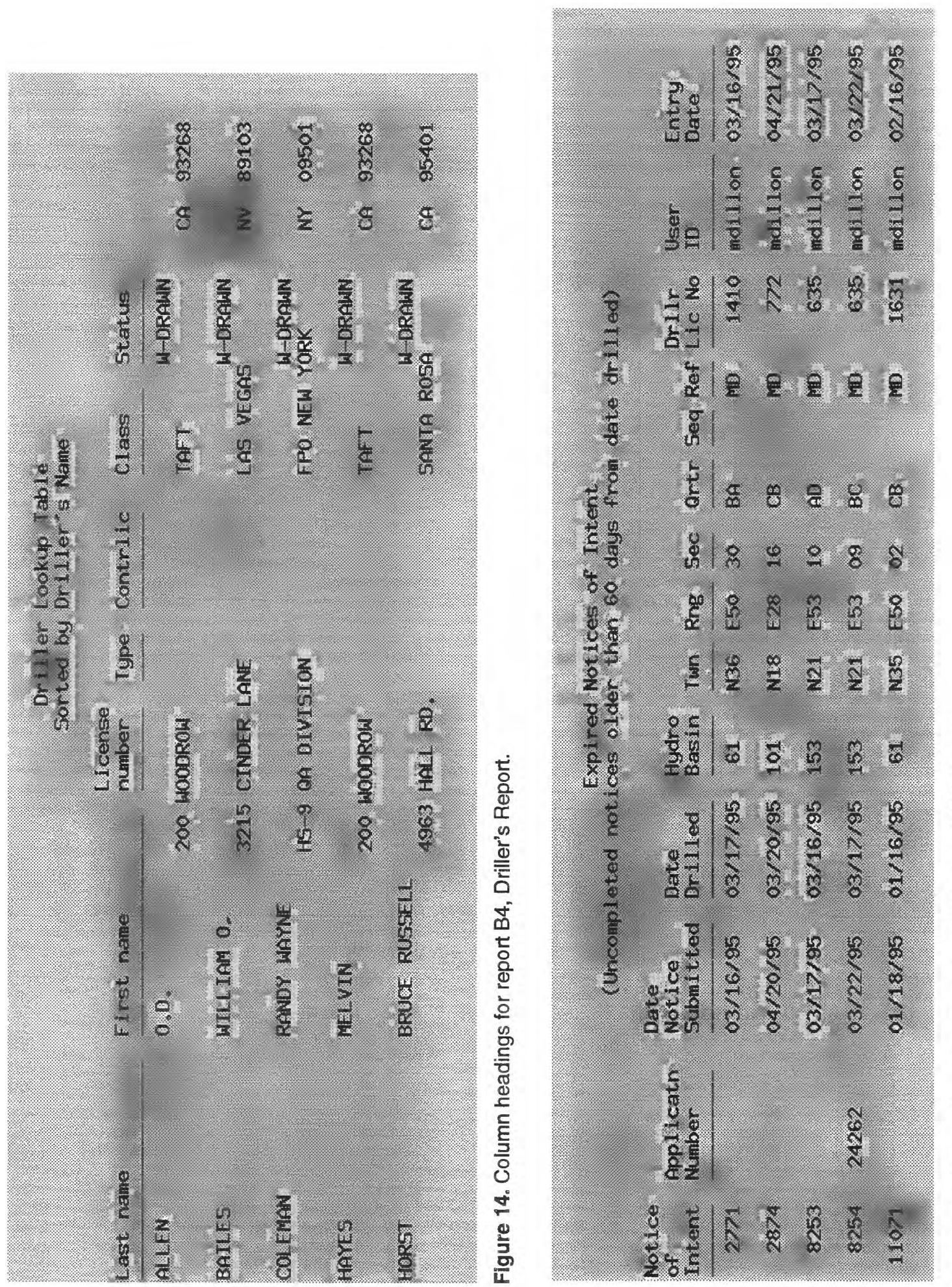

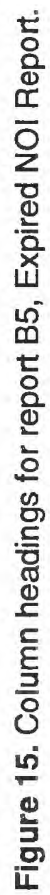



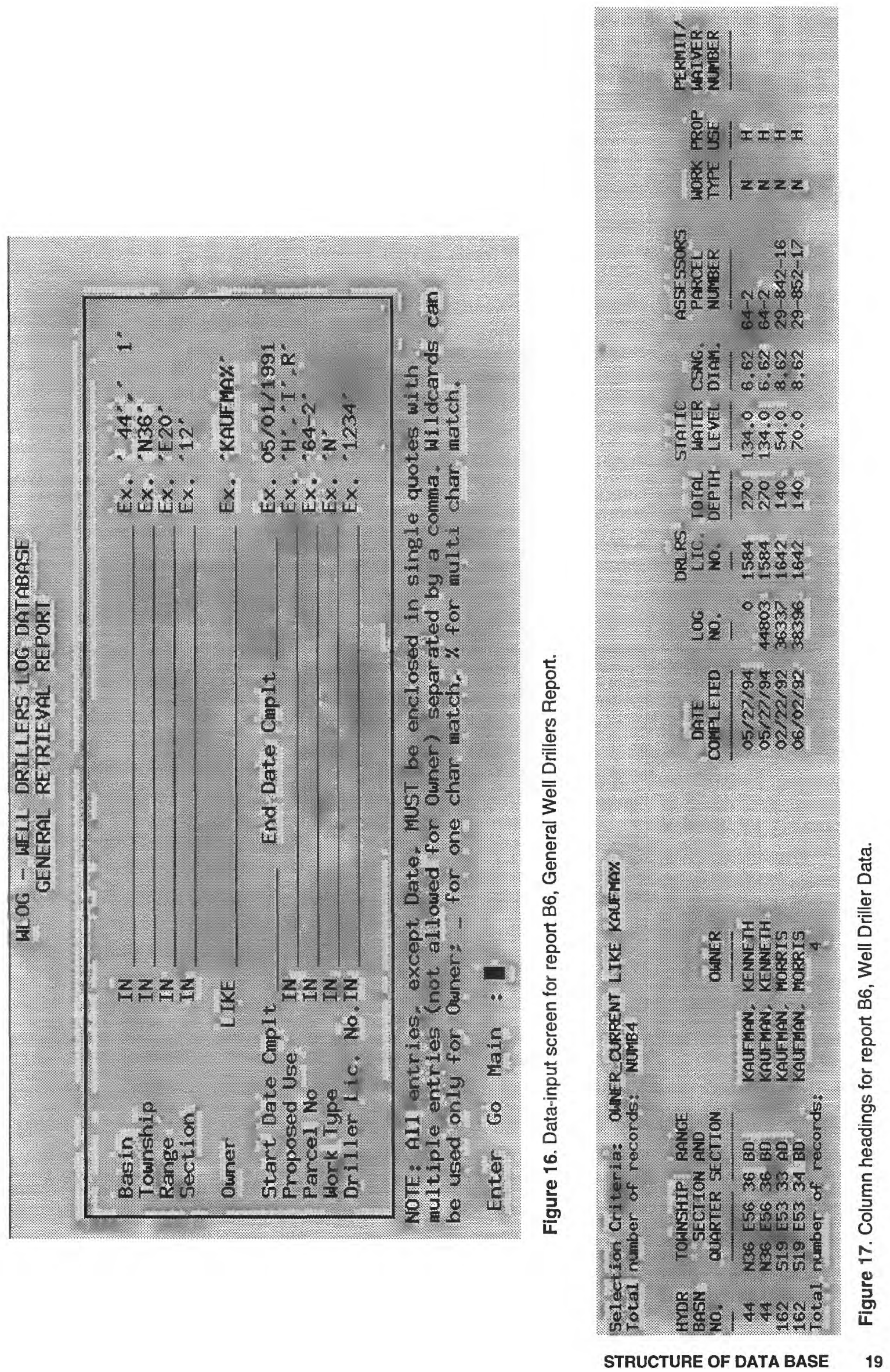

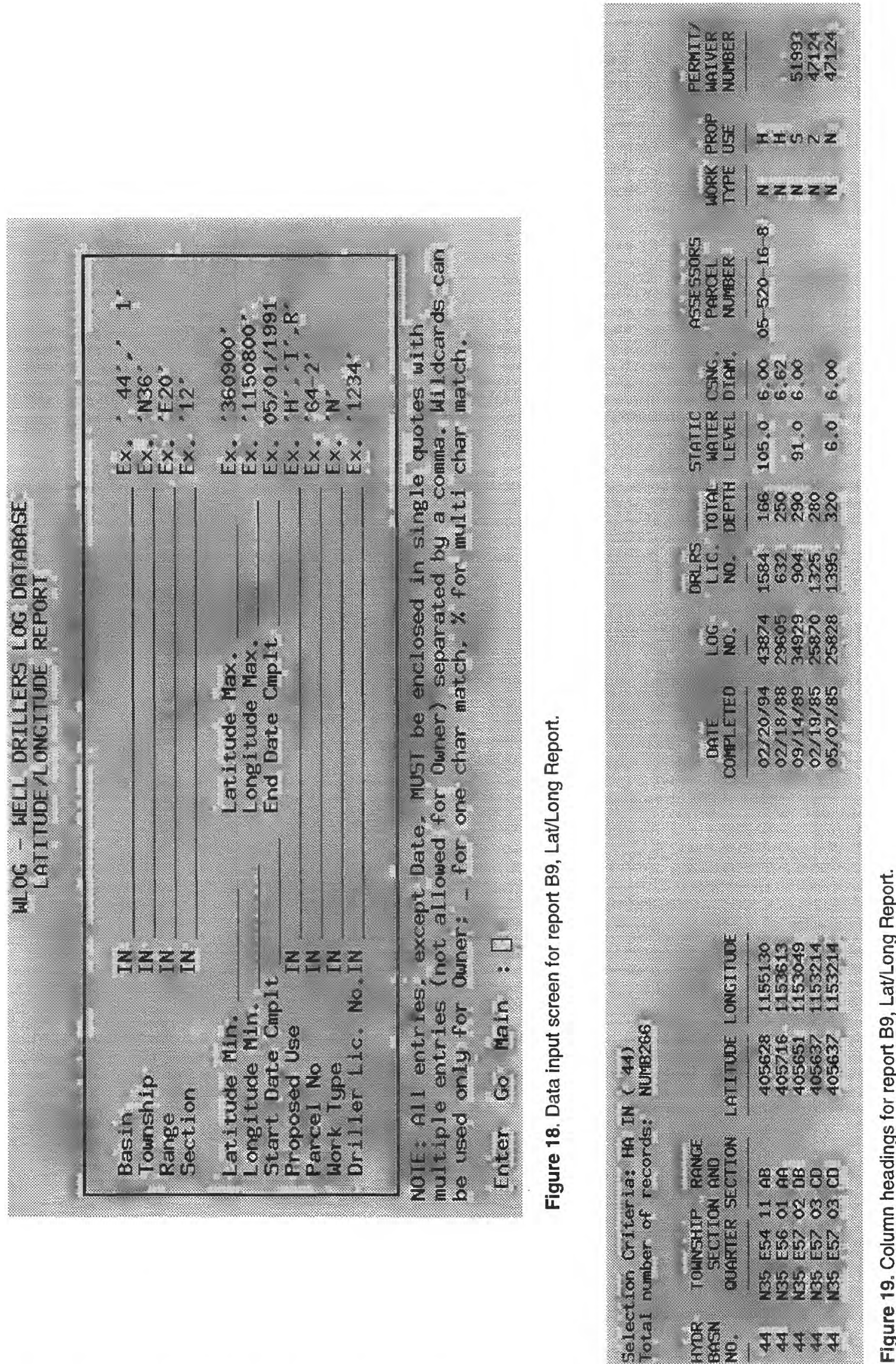


\section{REFERENCES CITED}

Nevada Division of Water Resources, 1990, Regulations for water well and related drilling: Nevada Division of Water Resources, $72 \mathrm{p}$.

Rush, F.E., 1968, Index of hydrographic areas in Nevada: Nevada Division of Water Resources, Information Report 6, $38 \mathrm{p}$.

Shamberger, H.A., 1991, Evolution of Nevada's water laws, as related to the development and evaluation of the State's water resources, from 1866 to about 1960: Nevada Division of Water Resources, Bulletin 46, $100 \mathrm{p}$. 
APPENDIX 


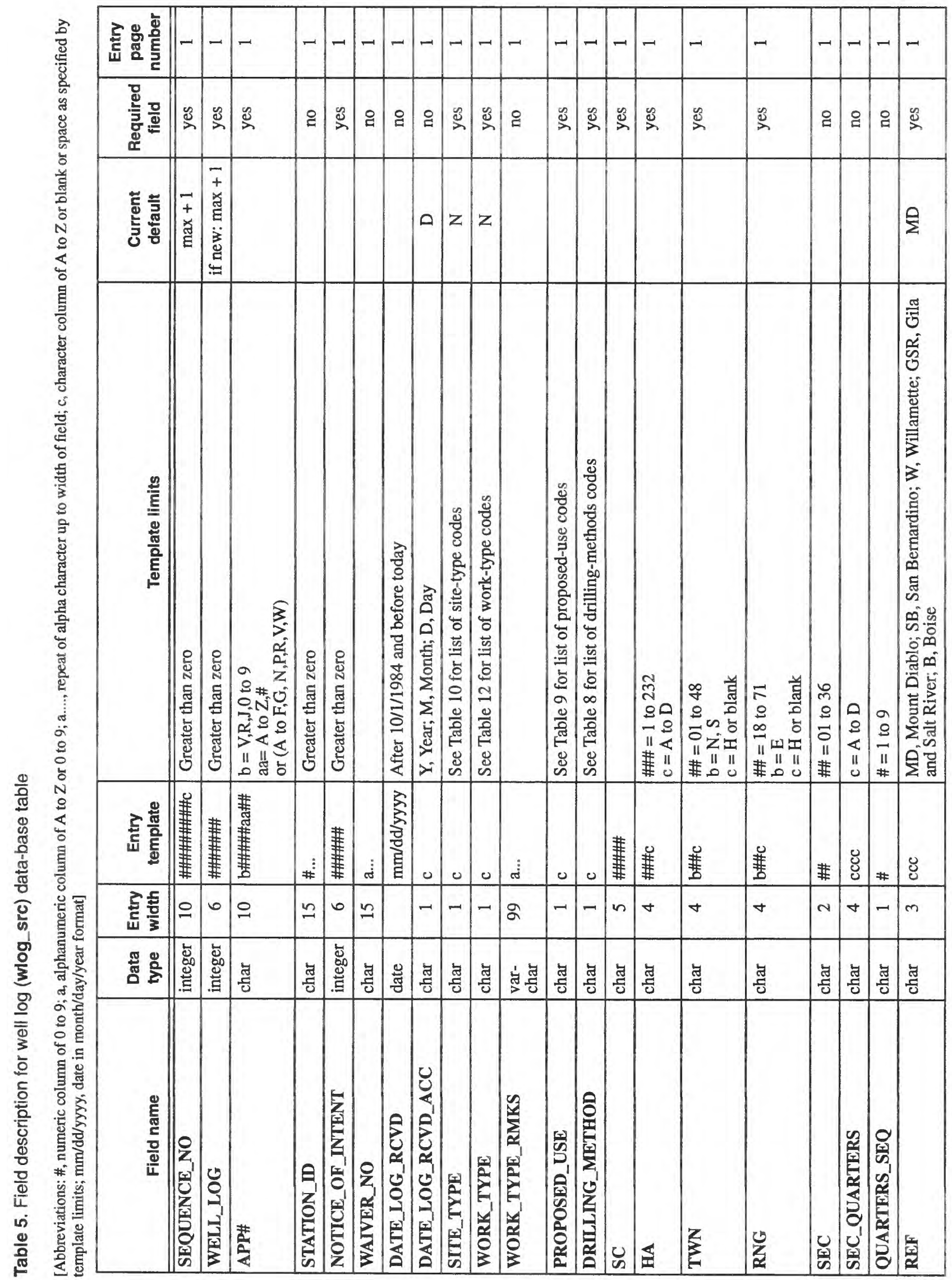




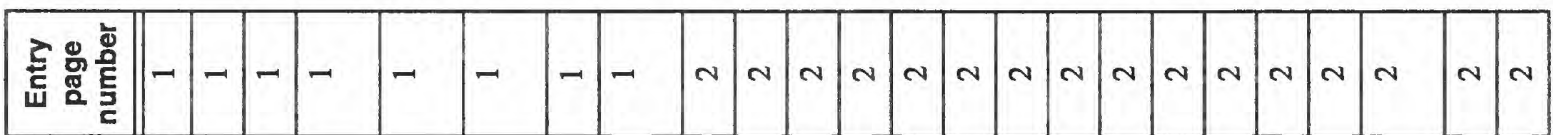

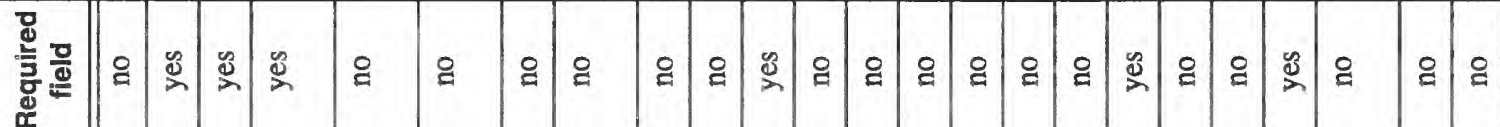

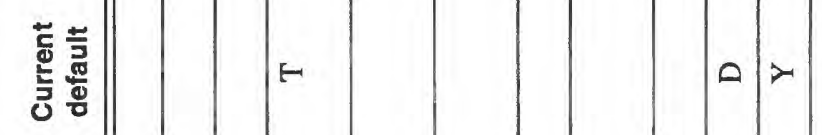

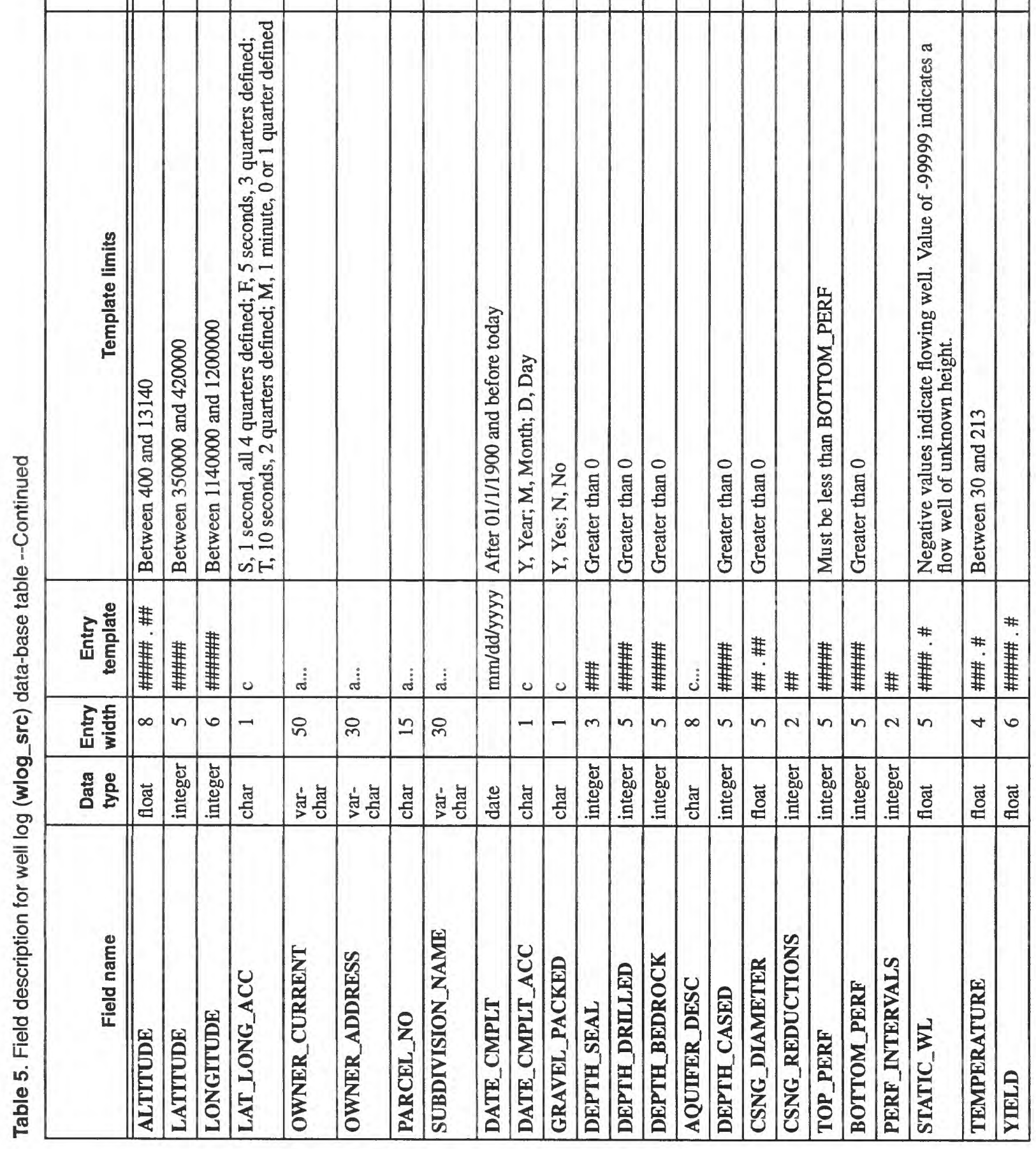




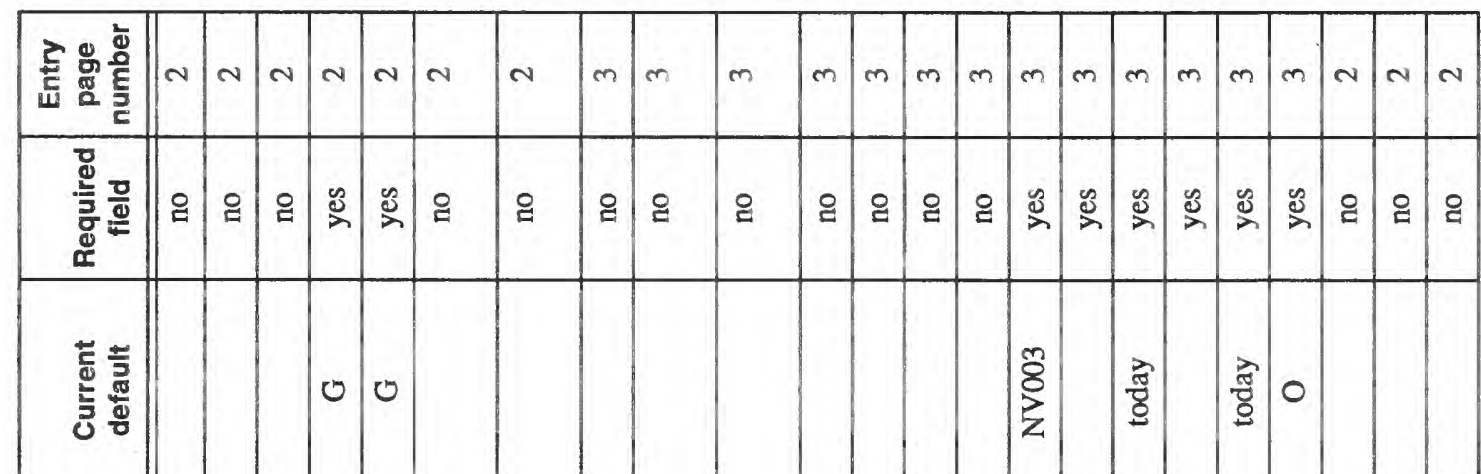

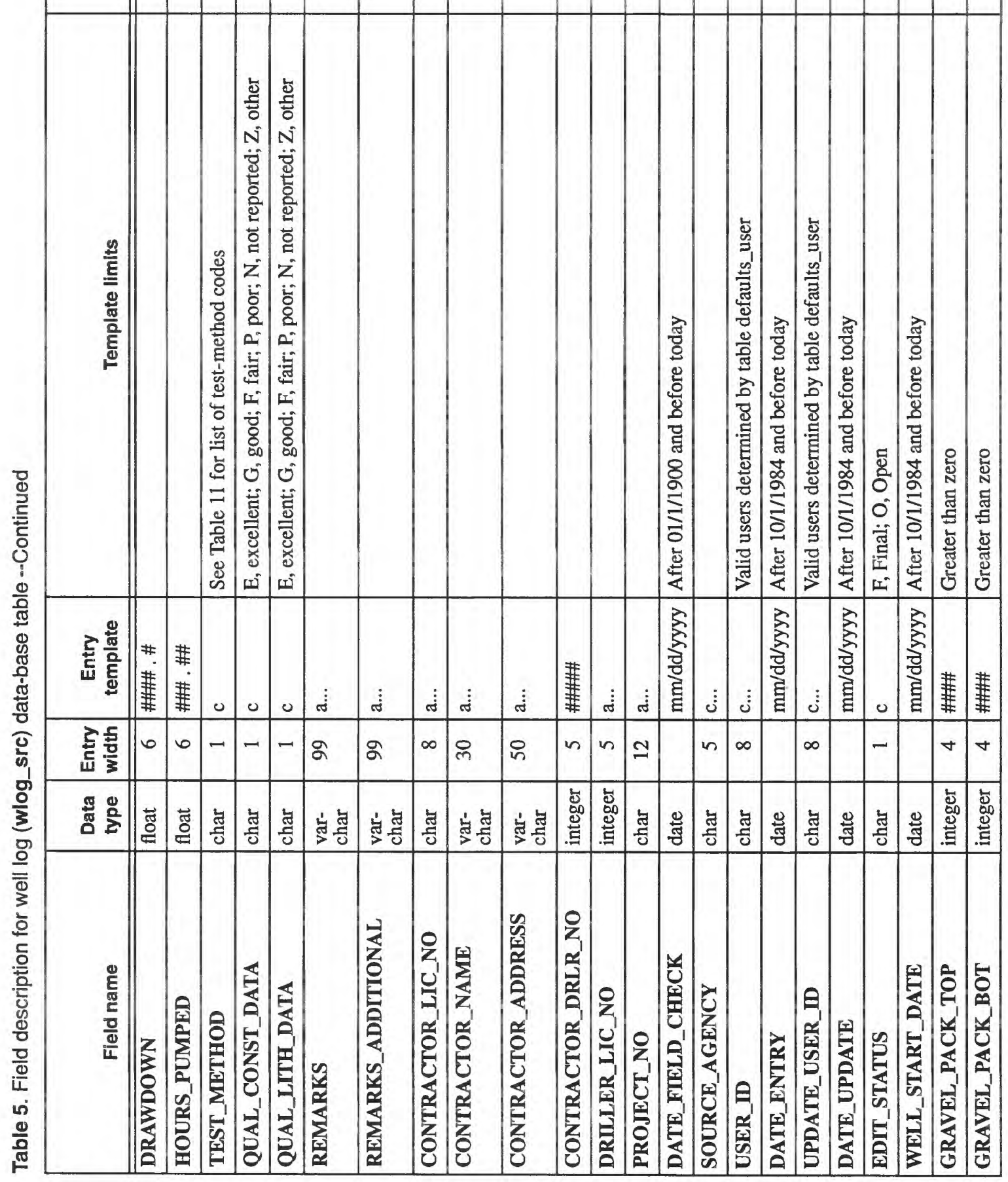


Table 6. Field description for notice-of-intent (intent_src) data-base table

[Abbreviations: \#, numeric column of 0 to 9 ; a, alphanumeric column of $A$ to $Z$ or 0 to 9 ; a...., repeat of alpha character up to width of field; c, character column of $A$ to $Z$ or blank or space as specified by template limits; $\mathrm{mm} / \mathrm{dd} / \mathrm{yyyy}$, date in month/day/year format]

\begin{tabular}{|c|c|c|c|c|c|c|}
\hline Field name & $\begin{array}{l}\text { Data } \\
\text { type }\end{array}$ & $\begin{array}{l}\text { Entry } \\
\text { width }\end{array}$ & $\begin{array}{c}\text { Entry } \\
\text { template }\end{array}$ & Template limits & $\begin{array}{l}\text { Current } \\
\text { default }\end{array}$ & $\begin{array}{c}\text { Required } \\
\text { field }\end{array}$ \\
\hline NOTICE_OF_INTENT & integer & $\overline{6}$ & \#\#\#\# & Greater than 0 & & yes \\
\hline APP\# & char & 10 & b\#\#\#\#cc\#\# & $\begin{array}{l}\mathrm{b}=\mathrm{V}, \mathrm{R}, \mathrm{J}, 0 \text { to } 9 \\
\mathrm{cc}=\mathrm{A} \text { to } \mathrm{Z}, 0 \text { to } 9 \\
\text { or }(\mathrm{A} \text { to } \mathrm{F}, \mathrm{G}, \mathrm{N}, \mathrm{P}, \mathrm{R}, \mathrm{V}, \mathrm{W})\end{array}$ & & no \\
\hline DATE_SUB & date & & $\mathrm{mm} / \mathrm{dd} / \mathrm{yyyy}$ & After $01 / 1 / 1900$ and before today & today & yes \\
\hline DATE_DRL & date & & $\mathrm{mm} / \mathrm{dd} / \mathrm{yyyy}$ & After $01 / 1 / 1900$ and before today & & no \\
\hline HA & char & 4 & $\# \#$ \# & $\begin{array}{l}\# \#=1 \text { to } 232 \\
c=A \text { to } D\end{array}$ & & no \\
\hline TWN & char & 4 & $\mathrm{b \# \# c}$ & $\begin{array}{l}\#=01 \text { to } 48 \\
b=N, S \\
c=H \text { or blank }\end{array}$ & & no \\
\hline RNG & char & 4 & $\mathrm{b \# \# c}$ & $\begin{array}{l}\text { W }=18 \text { to } 71 \\
\mathrm{~b}=\mathrm{E}, \mathrm{W} \\
\mathrm{c}=\mathrm{H} \text { or blank }\end{array}$ & & no \\
\hline SEC & char & 2 & \#\# & $\# \#=01$ to36 & & no \\
\hline SEC_QUARTERS & char & 4 & cccc & $c=A$ to $D$ & & no \\
\hline QUARTERS_SEQ & char & 1 & $\#$ & $\#=1$ to 9 & & no \\
\hline REF & char & 3 & ccc & $\begin{array}{l}\text { MD, Mount Diablo; SB, San Bernar- } \\
\text { dino; W, Williamette; GSR, Gila } \\
\text { and Salt River; B, Boise }\end{array}$ & & no \\
\hline OWNER_ADDRESS & $\begin{array}{l}\text { var- } \\
\text { char }\end{array}$ & 50 & a... & & & no \\
\hline DRILLER_LIC_NO & integer & 5 & a... & & & no \\
\hline USER_ID & char & 8 & c... & $\begin{array}{l}\text { Valid users determined by table } \\
\text { defaults_user }\end{array}$ & & yes \\
\hline DATE_ENTRY & date & & $\mathrm{mm} / \mathrm{dd} / \mathrm{yyyy}$ & After $10 / 1 / 1984$ and before today & today & yes \\
\hline SITE_ADDRESS & $\begin{array}{l}\text { var- } \\
\text { char }\end{array}$ & 50 & \begin{tabular}{|l|} 
a... \\
\end{tabular} & & & no \\
\hline WAIVER_NO & char & 10 & a... & & & no \\
\hline LOG_RCVD & char & 1 & $\mathrm{a}$ & & & no \\
\hline
\end{tabular}

Table 7. General description for lookup tables

\begin{tabular}{|c|c|c|}
\hline Field name & Description & Additional information \\
\hline \multicolumn{3}{|c|}{ agency_lut } \\
\hline SOURCE_AGENCY & Source agency code & $\begin{array}{l}\text { Agency or company where Driller's Log information } \\
\text { originated. Codes were previously established by USGS to } \\
\text { comply with their national data base }\end{array}$ \\
\hline SOURCE_NAME & Full name of agency code & \\
\hline \multicolumn{3}{|c|}{ basin_lut } \\
\hline HA & Hydrographic area & Based on hydrographic numbering system. See Rush, 1968. \\
\hline BASIN & Hydrographic basin & $\begin{array}{l}\text { Same number as HA, but with leading zeros to complete a } \\
\text { three digit code }\end{array}$ \\
\hline BASIN_NAME & Basin name & Actual name of the basin \\
\hline BASIN_STATUS & Basin status & $\begin{array}{l}\text { Status of basin regarding water rights, as ordered by the State } \\
\text { Engineer. Basin status is either designated or } \\
\text { nondesignated. }\end{array}$ \\
\hline
\end{tabular}


Table 7. General description for lookup tables--Continued

\begin{tabular}{|c|c|c|}
\hline Field name & Description & Additional information \\
\hline REGION & Region & $\begin{array}{l}\text { Code for hydrographic region. NDWR has defined } 14 \\
\text { hydrographic regions generally based on major hydrologic } \\
\text { drainage areas, which are further subdivided into } \\
\text { hydrographic areas for water planning and management } \\
\text { purposes. }\end{array}$ \\
\hline REGION_NAME & Region name & \\
\hline \multicolumn{3}{|c|}{ cont_lut } \\
\hline CONTRACTOR_LIC_NO & $\begin{array}{l}\text { Contractor's license } \\
\text { number }\end{array}$ & Issued by the State Board of Contractors \\
\hline CONTRACTOR_NAME & Contractor's name & Name of contractor drilling well \\
\hline CONTRACTOR_ADDRESS & Contractor's address & Address of contractor drilling well \\
\hline \multicolumn{3}{|c|}{ county_lut } \\
\hline SC & State and county code & $\begin{array}{l}\text { First two numbers are state code, last three numbers are } \\
\text { county code }\end{array}$ \\
\hline COUNTY & County & Two character county code \\
\hline COUNTY_NAME & County name & Full county name \\
\hline MIN_LAT & Minimum latitude & Display capability for GIS; currently not used. \\
\hline MAX_LAT & Maximum latitude & Display capability for GIS; currently not used. \\
\hline MIN_LONG & Minimum longitude & Display capability for GIS; currently not used. \\
\hline MAX_LONG & Maximum logitude & Display capability for GIS; currently not used. \\
\hline STATE_AB & State abbreviation code & Two character state abbreviation code \\
\hline STATE_CODE & State code & Two digit numeric code \\
\hline COUNTY_CODE & County code & Three digit numeric code \\
\hline \multicolumn{3}{|c|}{ drilling_mthd_lut } \\
\hline DRILLING_METHOD & Drilling method & Single character code to indicate method used to drill well \\
\hline DRILLING_METHOD_DESC & $\begin{array}{c}\text { Drilling-method } \\
\text { description }\end{array}$ & Full description of single character drilling-method code \\
\hline \multicolumn{3}{|c|}{ proposed_use_lut } \\
\hline PROPOSED_USE & Proposed use & Single character code to indicate principal use of water at site \\
\hline PROPOSED_USE_DESC & Proposed-use description & Full description of single character proposed-use code \\
\hline \multicolumn{3}{|c|}{ site_type_lut } \\
\hline SITE_TYPE & Site type & Single character code to indicate the current status of well \\
\hline SITE_TYPE_DESC & Site-type description & Full description of single character site-type code \\
\hline \multicolumn{3}{|c|}{ test_mthd_lut } \\
\hline TEST_METHOD & Test method & Single character code to indicate method of construction \\
\hline TEST_METHOD_DESC & Test-method description & Full description of single character test-method code \\
\hline \multicolumn{3}{|c|}{ work_type_lut } \\
\hline WORK_TYPE & Work type & $\begin{array}{l}\text { Single character code to indicate type of work that was } \\
\text { performed by driller }\end{array}$ \\
\hline WORK_TYPE_DESC & Work-type description & Full description of single character work-type code \\
\hline
\end{tabular}


Table 8. Codes for drilling methods used in drilling_mthd_lut

\begin{tabular}{|c|l|}
\hline $\begin{array}{c}\text { Drilling-method } \\
\text { code } \\
\text { (DRILLING_METHOD) }\end{array}$ & \multicolumn{1}{|c|}{$\begin{array}{c}\text { Drilling-method } \\
\text { description } \\
\text { (DRILLING_METHOD_DESC) }\end{array}$} \\
\hline \hline A & Air rotary \\
B & Bored or augered \\
C & Cable tool \\
D & Dug \\
H & Hydraulic rotary-mud \\
\hline J & Jetted \\
P & Air percussion \\
R & Reverse rotary \\
T & Trenching \\
V & Driven \\
\hline W & Drive and wash \\
Z & Other (explain in remarks) \\
\hline
\end{tabular}

Table 9. Codes for proposed use used in proposed_use_lut

\begin{tabular}{|c|l|}
\hline $\begin{array}{c}\text { Proposed-use code } \\
\text { (PROPOSED_USE) }\end{array}$ & $\begin{array}{c}\text { Proposed-use } \\
\text { description } \\
\text { (PROPOSED_USE_DESC) }\end{array}$ \\
\hline \hline A & Air conditioning \\
B & Bottling \\
C & Commercial \\
D & Dewater \\
E & Power \\
\hline F & Fire \\
H & Domestic \\
I & Irrigation \\
J & Industrial-cooling \\
K & Mining \\
\hline M & Medicinal \\
N & Industrial \\
P & Public sup-municipal \\
Q & Aquaculture \\
R & Recreation \\
\hline S & Stock \\
T & Institution \\
U & Unused \\
Y & Desalination \\
Z & Other (explain in remarks) \\
\hline
\end{tabular}

Table 10. Codes for site type used in site_type_lut

\begin{tabular}{|c|l|}
\hline $\begin{array}{c}\text { Site-type code } \\
\text { (SITE_TYPE) }\end{array}$ & $\begin{array}{c}\text { Site-type } \\
\text { description } \\
\text { (SITE_TYPE_DESC) }\end{array}$ \\
\hline E & Existing (deepen) \\
N & New \\
P & Proprietary-new \\
Y & Proprietary-existing \\
\hline
\end{tabular}

Table 11. Codes for test method used in test_mthd_lut

\begin{tabular}{|c|l|}
\hline $\begin{array}{c}\text { Test-method } \\
\text { code } \\
\text { (TEST_METHOD) }\end{array}$ & \multicolumn{1}{|c|}{$\begin{array}{c}\text { Test-method } \\
\text { Description } \\
\text { (TEST_METHOD_DESC) }\end{array}$} \\
\hline \hline A & Air lift \\
B & Bucket \\
C & Centrifugal pump \\
J & Jet pump \\
P & Piston pump \\
\hline R & Rotary \\
S & Submergible pump \\
T & Turbine \\
U & Unknown \\
Z & Other (explain in remarks) \\
\hline
\end{tabular}

Table 12. Codes for work type used in work_type_lut

\begin{tabular}{|c|l|}
\hline $\begin{array}{c}\text { Work-type code } \\
\text { (WORK_TYPE) }\end{array}$ & $\begin{array}{c}\text { Work-type } \\
\text { description } \\
\text { (WORK_TYPE_DESC) }\end{array}$ \\
\hline \hline D & Deepen \\
G & Geothermal \\
N & New \\
O & Other (explain in remarks) \\
\hline P & Plug or abandonment \\
R & Recondition \\
T & Test \\
\hline
\end{tabular}

